\title{
DECISIONS, DECISIONAL REFERENTS, AND ADMINISTRATIVE JUSTICE
}

\author{
Daniel J. Gifford*
}

This article is an attempt to share some developing thoughts on the major problem of discretionary justice, which Professor Davis has brought to our attention. I first examine the contributions of the linguistic school of legal philosophy towards the development of our understanding of discretion. In that examination we find that informal and largely internal constraints may be operable upon decision-making, and we also find that many of these constraints may be invisible. Next (in Part II), from the inference that decisions are constrained or guided by factors which have hitherto tended to escape the sustained attention of lawyers, I attempt, in a preliminary way, to develop a conceptual structure in which to take cognizance of these factors. This structure, which I refer to as one of "decisional referents," I follow up (in Part III) by examining some examples of official decision-making, and by probing to find the effects of structure upon tendencies toward change and growth and upon countervailing tendencies toward stability. In Part IV, I pursue an examination of a decisional-referent conceptualization of official decision-making for its implications concerning the related factors of openness and substantive rationality. Finally (in Part V), I assess some of the recent developments in administrative standing in the light of this conceptual structure.

I

\section{The Significance of "Internal" Constraints on the Exercise of Discrettonary Power}

\section{A. Discretion and Internal Constraints}

Davis finds discretion present in any situation in which "the effective limits on ... [an official's] power leave him free to make a choice among possible courses of action or inaction." $\mathrm{He}$ includes within that concept power to make unauthorized decisions "because a good deal of discretion is illegal or of questionable legality." In this article, I will depart from Davis's definition of the problem and confine myself largely to a consideration of "authorized" discretion. I will, however, return periodically to Davis's emphasis upon the "effective limits" of an official's power.

Davis's assertion that he is concerned with unauthorized as well as with authorized discretionary power and his stress upon the need for "effective limits" on decisionmaking power may be somewhat misleading. The critical factor is the meaning of

\footnotetext{
- Professor of Law, State University of New York at Buffalo.

${ }^{2} \mathrm{~K}$. Davis, Discremonary Justice 4 (Ig6g).

${ }^{3} I d$.
} 
the "effective limits" phrase. Certainly, the implication of his writing is correct that limits upon the authorized discretion of an official are unimportant in those cases in which that official pays little heed to the limits of his authorized power. But, in the case of officials who have internalized the rules of the system within which they work, a latent ambiguity in Davis's phrasing appears: to the extent that officials have in fact internalized the system's rules, limitations on their authorized powers will be "effective." I am assuming here an empirical meaning for effectiveness, that is, that an "effective" limit is a limit which works.

Among those who have most recently directed their attention to an internalization of rules by officials are the legal philosophers Dworkin and Hart. Both men have drawn attention to the "binding" effect which externally made rules have upon a decision-maker who has internalized the legal system in which he functions as an official. Hart first made the point about the effectiveness of internal constraints when he pointed out that a judge in a court of last resort could be "bound" by prior cases or principles embodied in the legal system even though, were he to ignore those cases or principles, his decision would be irreversible. ${ }^{8}$ Dworkin followed Hart's approach in a discussion of administrative and judicial discretion. ${ }^{4}$ Dworkin there attributed discretion only in a "weak" sense to an official whose decisions are either a matter of judgment or unreviewable or both but discretion in a "strong" sense to an official who has been entrusted decision-making power but with no standards for the exercise of that power supplied to him by the authority vesting him with it. ${ }^{5}$ In the case of "weak" discretion, the official is "bound" by standards supplied by the external authority although that authority may not, especially in the second case, enforce those standards against him. The official, however, is not free to decide any way he wishes. He is free only in case he decides to flaunt the imperatives of the system in which he acts. So long as he identifies with that system, he internalizes the "obligation" which the system imposes upon him to decide in accordance with its mandates; he is in effect "bound" by its rules.

It is tempting, at this point, to assert that effective limits on discretionary power exist when officials internalize the system's rules. But at least two difficulties inhere in this method of statement: first, officials probably are not separable solely into two categories composed, respectively, of those who accept the system's rules and of those who do not. Some officials will accept some of the system's rules but not others, and some rules will be accepted to a greater degree than will others-that is, more temptation or inducement to depart from some rules will be required before they are disregarded than in the case of other rules. This is merely to suggest that the degree to which the system's rules are internalized will vary with the rule and with the official.

But, second, this method of statement is overly "rule" oriented. In focusing upon

\footnotetext{
${ }^{8}$ H.L.A. Hart, The Concept of Law 56, 141-42 (1961). See also id. at 56, 86-88, 139-44.

'Dworkin, The Model of Rules, 35 U. CrI. L. REv. $14,32-40$ (1967).

${ }^{5}$ Id. at 32-33.
} 
an internally felt obligation to adhere to rules as a constraint upon an official's exercise of power, it leads us away from the discretion which is conveyed by rule ambiguity and imprecision. In cases in which the "rules"-if they are observed-do not determine the outcome of a case, the decison-maker appears to have discretion both in Davis's "effective limits" sense and in Dworkin's "strong" sense. ${ }^{\text {.a }}$ It is to those cases, then, that our present inquiry is directed: where will we find the criteria which are or should be used for decision and what methods are available for improving the consistency and the quality of those criteria?

\section{B. An Extrapolation of the Hart-Dworkin Insight: Conformity to Self-created Rules}

Hart and Dworkin, in pointing out that an official might be effectively constrained in his decision-making by his recognition of the "obligations" which the legal system imposes upon him, have focused upon a situation in which an official is supplied with decisional criteria by an external authority and internalizes an obligation to apply those criteria. But the constraints which can be created by internalization may go further. Let us consider a situation in which a statute commits decisions of a certain kind to an agency and in which the agency redelegates the decision-making function to one official, who then develops rules governing his . exercise of that power. And let us further suppose that this official does not publish or otherwise disseminate those rules to other persons within or without the agency. Davis has given us just such an example, ${ }^{6}$ in his description of an official in the Justice Department who decided cases involving remission and mitigation of automobile forfeitures incurred for violating the narcotics laws. ${ }^{7}$ His decisions were, so far as the governing statute was concerned, fully discretionary. Indeed, the statute expressly commits such decisions to administrative discretion. ${ }^{8}$ Yet in Davis's description, the official had worked out a set of elaborate rules to govern the cases coming before him, with the result that he decided pursuant to that set of rules, and exercised little or no discretion in deciding individual cases. ${ }^{9}$ Although his decisions invariably conformed to this set of rules, those rules were unknown not only outside of the agency but within it. Their content was known only to their creator, the official entrusted with the task of making the remission and mitigation decisions which, in practice, were governed by those rules. In such a situation, is it correct to assert that the decision-maker has discretion? Or is it more correct to assert that his action is so governed by rules that he has little or no discretion? Or, in this context, is the term "discretion" still useful? Observe that even Dworkin's three

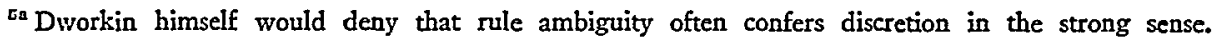
Rather, he would assert that an official who confronts rule ambiguity is most frequently obliged to resolve the ambiguity in accordance with "principles" or other guides furnished by the legal system in which he operates. Dworkin, supra note 4 at 36-46; Dworkin, Social Rules and Legal Theory, 8I YALE L.J. 855,879 (1972).

$\mathrm{K}$. Davis, supra note I, at Iog-rI.

${ }^{7}$ r9 U.S.C. \$§ 1595a, 1618 (1970).

8 I9 U.S.C. \$ I6I8 (1970).

- K. Davis, stupra note I, at rog.
} 
senses $^{10}$ of discretion are of little value in answering these questions. While the official has discretion in all three of Dworkin's senses, his actions are governed by rules, albeit not externally made rules. If he always decides in accordance with those rules, do not those rules in fact act as the "effective limits"11 on his decisionmaking which Davis seeks?

Even if we conclude that it is accurate to describe the official who invariably conforms to his own set of unpublished rules as possessing discretionary power, it is also accurate to describe him as habitually failing to employ that discretion. Davis here, of course, would point out that the official may sometime actually employ the discretionary power which he now "possesses" but does not now "use." But even a conclusion that the official possesses unexercised discretionary power is not a simple statement. If the official never "uses" discretion which he is said to "possess," the reality of his asserted possession of discretionary power is at least questionable. Certainly, there are reasons why that power is not employed, and we need to inquire when, if at all, these reasons are likely to permit the employment of that power. ${ }^{12}$

Davis's actual criticism of the arrangement involving the official who created his own rules is centered on the secrecy of the rules and seems to be concerned primarily with the fact that no external constraints prevent the official from departing from his rules in individual instances. ${ }^{13}$ But a focus upon external constraints tends to obscure the fact that the decision-maker himself decided to adopt his set of rules and has been applying them. Perhaps we should ask why the rules were created and the extent to which the decision-maker feels an obligation to apply those rules. If the decision-maker feels a sense of obligation or duty to apply the rules which is strong enough to overcome his personal desires in individual instances, then could we not conclude that his decisions are in fact constrained, even in the absence of external constraints? Could we not admit that some constraints on decision-making might be internal to the actor himself? $\mathrm{Or}$, if the decision-maker could alter or

\footnotetext{
${ }^{10}$ See text accompanying notes 4-5 supra.

${ }^{11}$ See text acompanying note I supra.

12 This inquiry began with the "legal realist" writers of a generation ago. Many of these writers directed their attention to the factors, psychological, political and other, which influence judges' decisions within the free scope provided by the ambiguities of the laws. See notes 21 and 25 infra. As suggested in text, an official may be effectively confined to a set of rules or to the use of a set of "referents" through a sense of "obligation." He also may experience external imperatives towards consistency of action from formal or informal bureaucratic controls. Again, a constraining influcnce may arise when decisions must be made in routine cases which occur in large numbers; consistency must be maintained to preserve the integrity of a set of rules which comprise the means by which an official copes with a voluminous caseload. Cf. Friedman, On Legalistic Reasoning-A Footnote to Weber, 1966 WIs. L. REv. 148, 157. Former Chairman Cary of the Securities and Exchange Commission has described how he was able to avoid some external constraints-consisting of pressures brought by business and political sources-by carefully choosing the manner of acting: adjudication rather than rule-making. See W. Cary, Polimics and the Regulatory Agencies 83-84 (1967).

The "costs" to an official or agency-in effectiveness, in organizational stability, in psychological satisfaction-of resisting external pressures would be a proper subject of study. The focus of this article, however, is largely upon the substantive inputs into the decisional structure, that is, upon the content of assertedly "discretionary" decisions.

${ }^{23} \mathrm{~K}$. DAvis, supra note $\mathrm{I}$, at $\mathrm{I}$ Io.
} 
waive his rules only at some cost, could we not admit that a constraint-measurable by the extent of the cost which would otherwise be incurred-was present and which operated to induce decisions in conformity with his rules? An affirmative answer to any one of these questions suggests a need to inquire whether all constraints on decision-making need be external to the actor. By implication, such an answer also suggests that we need to examine the existence and strength of internal constraints. This approach will also facilitate our inquiry into constraints (or constraining influences) external to the actor which are informal and which, therefore, may be easily overlooked by lawyers.

\section{Internal Constraints and the Appearance of Nonexistent Discretion}

The Hart-Dworkin insight into the relevance of rule-internalization for understanding discretion is useful in differentiating the appearance from the reality of discretion-a differentiation which is sometimes obscured under more-or-less traditional perceptions of administrative discretion. Thus, under the traditional view of administrative discretion, there tends to exist a negative correlation ${ }^{14}$ between the predictability of a decision and the extent of the decision'-maker's discretion: When the facts are clear or undisputed, the content of a decision is highly predictable in those cases which involve a governing rule in its "core"15 area of application; and in this kind of case the decision-maker has little or no discretion. But when the case involves situations which depart from the governing rule's core area of application -or when it is uncertain which of several apparently conflicting rules governthe decision becomes increasingly unpredictable, and the decision-maker's discretion is, accordingly, said to increase. ${ }^{16}$

This traditional description, however, is inaccurate in at least two respects: it neglects, first, the distinction between decisional ambiguity ${ }^{17}$ perceived by the decision-maker and decisional ambiguity perceived by an observer. These perceptions

\footnotetext{
${ }^{14}$ Cf. H.L.A. HART, THE CONCEPT of LAW I43 (xg6I); Cohen, Transcendental Nonsense and the Functional Approach, 35 Colum. L. Rev. 809, 843 (1935).

${ }^{25}$ On the distinction between a "core" area of word meaning or rule application and "pennumbral" areas, see Hart, Positivism and the Separation of Law and Morals, 7I HARv. L. Rev. 593, 606-08 (I958); Fuller, Positivism and Fidelity to Law-A Reply to Professor Hart, 7x Harv. L. Rev. 630, 66r-69 (x958); Gifford, Communication of Legal Standards, Policy Development, and Effective Conduct Regulation, 56 CORNeLL L. REv. 409, 426-30 (I97I).

The distinction, in its current form, is derived from the preoccupation of British and American philosophers in recent decades with the open-texture of all language. See, e.g., L. Wrtrgenstein, PhILOsophical Investigntions (G. Anscombe transl. I953); Waismann, Verifiability, in Essays in LoGic aND LANGUAGE II7 (Ist ser., A. Flew ed. I95I). The impact of such open-texture for law has been pointed out, inter alia, in H.L.A. HART, THE CONCEPT of LAW I2I-32 (I96I); Hart, The Ascription of Responsibilities and Rights, 49 Procendings of the ARIsrotelian Soc'y (n.s.) I7I, I73-74 (1948-49). Kelsen long ago, however, pointed out that vagueness, ambiguity, or conflict in directives addressed to officials confers discretionary decision-making power upon those officials. Kelsen, The Pure Theory of Law, 50 L.Q. REv. 474 (I934).

${ }^{10}$ See note 15 supra. See also notes 20 \& 21 infra.

17 The phrase "decisional ambiguity," as used in the text, includes all situations in which the correct decisional result is uncertain. It includes cases in which that uncertainty results from ambiguity in the decisional norms, as well as cases in which that uncertainty results from vagueness or imprecision in those norms or from conflict among decisional norms.
} 
are not always the same. An extreme example of a difference in such perceptions is presented by the situation in which an official appears to an outside observer to possess discretion because no statute or promulgated rules compel a decision one way or another but in which he actually has little or no discretion at all because his decisions are governed by a set of rules known and acted upon within that official's agency but unknown outside of it. ${ }^{18}$ But the internal-rule situation is only an extreme form of a disparity in the perceptions of decisional freedom by a decisionmaker and his onlookers. In other circumstances, the decision-maker will feel bound by prior practice, trade custom, analytical techniques, and so forth, all of which may be unknown to at least some onlookers. The obligation which he feels to utilize those factors in deciding may or may not be enforced by his superiors. His decisions may even be unreviewable. Yet he may feel that the decisional system in which he functions requires him to utilize these factors in deciding. He may be "bound" in the Hart-Dworkin sense. An observer, however, who is unaware of these factors and of the official's concomitant "obligation" to employ them sees discretion which the official does not see. Finally, even when both the decision-maker and the onlookers perceive the same prospective decision in a similar analytical framework, they may differ in their respective assessments of the degree of decisional freedom present in that framework. ${ }^{19}$ The degree to which a given set of rules and other constraints forecloses (or does not foreclose) a decision-maker's freedom is frequently a matter of perception and judgment, and persons differ in their capacities for both. And this, at least partially, explains why an observer may confidently expect a decision in' a certain way and then be surprised to learn that the deciding official had decided in a way which the observer had thought impossible, or, again, why the official may consider himself bound by precedent in a case in which an observer sees large amounts of decisional discretion.

Second, the preceding description not only neglects the distinction between decisional ambiguity perceived by the decision-maker and decisional ambiguity perceived by an observer, but it also neglects the related distinction between the decisional ambiguity initially perceived by the decision-maker and the full or partial resolution of that ambiguity by him in the course of deciding. Here I focus upon a decisional situation which is initially perceived as ambiguous by the decision-maker (and perhaps by onlookers as well). But the need to decide compels the decision-maker to resolve that ambiguity. ${ }^{20} \mathrm{He}$ may resolve it by research, consultation, weighing alternatives, or other means, but resolve it he must. Because an observer may lack access to all of the information sources available to the decision-maker and because he necessarily lacks access to the later's mental processes in which judgments and evaluations are made, the observer cannot predict with

\footnotetext{
${ }^{18} \mathrm{Cf}$. text accompanying notes 6-9 supra.

${ }^{10}$ See, e.g., J. Frank, LAW AND TFE MODERN MiNd 164-65 (1963 ed.) and note 21 infra.

${ }^{20}$ Judge Hutcheson has described the perplexity of a judge facing a situation of decisional ambiguity and has noted the absence of predictability in those situations. Hutcheson, Lawyer's Law and the Little, Small Dice, 7 Tulane L. Rev. I, 8 (1932). See also note 21 infra.
} 
assurance how that ambiguity will be resolved. He may thus see the decision as discretionary with the decision-maker. Yet the latter may feel no such discretion at all. The difference is due to the fact that the observer is not privy to the processes by which the initial ambiguity is resolved. ${ }^{21}$ Thus, in a situation in which the relevant decisional norms appear ambiguous both to the deciding official and to an observer, the former may feel bound to resolve that ambiguity in accordance with the mandates of the legal system in which he is acting and, accordingly, to ferret out, if possible, the latent meaning of the governing rule or rules. In a very simple example, both the deciding official and an observer may initially perceive ambiguity in the decisional norms. But the deciding official may then resolve that ambiguity by reference to information sources, such as the legislative history of those norms. If these sources are not available to the observer, he cannot predict the official's decision. ${ }^{22}$ That decision, if it is not explained on the basis of the legislative history resorted to, may even appear to the observer to have been completely discretionary with the deciding official. Yet, to the deciding official, after he had researched the legislative history of the statute or other rule in question, the decision appeared controlled by a statute or rule whose purpose was disclosed by that history.

But the problem is more complex than this. Decisional ambiguity is frequently the result of vague, ambiguous, or conflicting statutes or rules inhering against a background of principles-generally largely shared by the decision-maker-mandating, when at all possible, decisions which are, among other things, "just" and compassionate. Thus, when the statutory purpose seems to require one result while justice or compassion require a different.one, or when several statutory or policy goals conflict in their application to the case at hand, decisional ambiguity results. Dworkin, ${ }^{23}$ for one, has attempted to describe this process where judicial decisionmakers struggle to apply correctly justice or equity or other "principles" supplied by the legal system in which they participate. In all of these situations, the system requires the official to find ways, if possible, of reconciling the apparent conflicts and, to the extent that this is impractical, to assign weights to the conflicting goals. In resolving the initial decisional ambiguity which confronts him, the decision-maker

\footnotetext{
${ }^{21}$ In his famous essay, The Judgment Intuitive: The Function of the "Hunch" in Judicial Decision, I4 Connel. I. Rev. 274 (1929), Hutcheson described the mental processes by which initial decisional ambiguity is often resolved, and he there differentiated those processes from the rationalization of the decision in the judge's written opinion. Hutcheson is not, however, describing processes in which a judge injects his personal whims which differ from his perception of the mandates of the legal system in which he participates. Rather, he appears to be describing processes in which the judge strives to resolve decisional ambiguity in accordance with a sense of justice which is seen as pervading that legal system. Compare J. Frank, LAw AND THE Modern Mind I6 $6-65$ (Ig63 ed.) where it is observed that most judges attempt to decide in accordance with their perceptions of the legal system's mandates. The less aware judges, however, deceive themselves into applying precedents and rules, unconscious of the discretion which existing formulations of these precedents and rules give them and oblivious to the policy choices which they are in fact making.

${ }^{22}$ See, e.g., United States v. Public Util. Comm'n, 345 U.S. 295, 3I9-20 (I953) (Jackson, J., concurring); Schwegmann Bros. v. Calvert Distillers Corp., 34I U.S. 384, 396-97 (I95I) (Jackson, J., concurring).

${ }^{28}$ Dworkin, supra note 4 .
} 
may not feel himself free to decide as he pleases. He may feel himself bound to decide in accordance with the principles, rules, goals, and so forth, which the system has supplied to him. His ability to reconcile apparent conflict will depend upon his own imagination; and the weights he accords to different goals and principles will often reflect his own perception of the system's priorities. His own preferences will also enter directly, as in some cases the system will entrust him with discretion in a "strong" sense." But, for the most part, the official will be struggling to apply the system's priorities as he can best perceive them. His decisions will tend to be perceived by him as strongly constrained by the information at his disposal and by his perception of the decisions, policies, and goals of the system which he is administering.

In the type of situation described, an observer, as well as the decision-maker, may perceive the initial decisional ambiguity. But since it will be exceedingly difficult, if not impossible, for the observer accurately to predict the manner in which the official will resolve the ambiguity, he is tempted to assert that the decision is discretionary with the official. Indeed, this was suggested by some of the so-called "legal realist" writers earlier in this century. ${ }^{25}$ But, as we have seen, such an assertion may not at all accord with the perceptions of the deciding official. Once he has resolved the ambiguity in accordance with the system's mandates as he perceives them, the official feels bound to decide in accordance with that resolution. While the "binding" nature of the official's resolution is perceived by him as a result of his own struggle to accord to the relevant factors the priorities which the system demands of them, because an external observer has not participated in that struggle and because an external observer would not necessarily have arrived at the same balance of those competing factors, the observer will often rightly fail to preceive the "obligation" felt by the decision-maker to decide the way that he did. The result is an externally perceived decisional freedom which is not at all perceived by the decision-maker.

\section{Summary}

Constraints upon the exercise of discretion can be real, even though they are largely internal and self-imposed. But the range of constraints is not exhausted in a dichotomy between "internal" and "external" constraints. Some constraints fall intermediate between the poles of internality and externality. Illustrative of this middle ground are the constraints described by Hart and Dworkin which have an external origin but which bind only those officials who have internalized the authority of their legal system to impose such obligations. But even the Hart-Dworkin model of constraints must be extended because the perception and un'derstanding by officials of the constraints imposed by the legal system will vary, and not all officials will

\footnotetext{
${ }^{24}$ Dworkin, stpra note 4 , at 33 .

${ }^{35}$ See, e.g., Haines, General Observations on the Effects of Personal, Political, and Economic Influences in the Decisions of Judges, I7 ILx. L. Rev. 98 (1922). Cf. Schroder, The Psychologic Study of Fudicial Opinions, 6 CaLIF. L. Rev. 89 (Ig18). See also note 21 supra.
} 
internalize every constraint established by the system. Moreover, those who do internalize will not all internalize all obligations with the same degree of intensity.

Some types of internal constraints operable upon officials are invisible to observers. Other constraints which are now largely unnoticed by such observers would be more visible if the observers knew where to direct their attention. If constraints upon decision-making include a spectrum of constraints from those which are fully external (in the sense that they are fully visible and enforced through supervision or other formal checking device) through those which are completely internal, then it is incumbent upon lawyers concerned to understand official decision-making to develop a conceptual framework which will facilitate the recognition of constraints which are wholly or partially internal to the decision-maker and which will engender among lawyers abilities to cope with and even to utilize these constraints to advantage. Especially in the more structurally-oriented task of law reform, a developed understanding and appreciation of the roles performed by internal constraints are likely to be highly useful.

But perhaps here it is time to examine our use of the term "constraint." "Constraint" suggests that a decision-maker is compelled to act in a way which is against his will. Yet a decision-maker who internalizes to a high degree the mandates of the legal system may not perceive those mandates as constraints; for him they may be welcome "guides" or "aids" in the performance of what otherwise would be a hopelessly complex and difficult task. Perhaps, then, instead of focusing exclusively upon constraints or constraining influences, we should direct our attention toward the guides or factors which officials in fact utilize in their decisional processes. Such a focus would include within our inquiry those rules, standards, criteria, or factors which the legal system requires officials to use and hence which may be "constraints" upon officials who have not internalized those factors completely. But it will also include, as within our inquiry, factors which conscientious officials employ in their decisional processes out of a sense of propriety but which they may not perceive as "constraints." Such an expanded inquiry would be likely to improve our understanding of discretionary decisional powers and their exercise, to increase our sensitivity to factors which do affect or control decision-making, to enable us to utilize these factors to advantage in dialogue with administrators, and to perceive the directions toward which some changes in decisional structure may tend.

II

\section{"Referents" and the Process of Decting}

One way of viewing the decisional process is to focus upon the needs of a deciding official, first, to ascertain the relevant facts and, second, to apply to those facts the appropriate decisional standard. The process is not always so straightforward, however, because the selection of those facts which are "relevant" depends upon the decisional standard to be applied, and the choice of the decisional standard depends, at least in part, upon the facts. Nonetheless, the relation between the 
facts and the decisional standard is not entirely circular: the totality of the concrete facts exerts an often controlling influence upon the choice of a decisional standard, and sometimes that choice is also influenced by the goals or other motives or sensitivities of the decision-maker. It is this latter aspect that I wish to focus upon in the present article. What determines the choice by a decision-maker of the standards which he will employ in deciding?

Two comments upon this question are immediately in order. First, observe that the question, as phrased, departs slightly from most inquiries into standards in administrative decision-making. Most such inquiries have focused upon the needs for standards as an aid to consistency. They have largely avoided asking why one standard is employed rather than another, and have instead asked why standards as such-regardless of the content of those standards-have not been forthcoming. Second, the term "standards" was used in the question in order to stress the connection between that question and the traditional inquiries into the needs for guides for consistency in administrative decision-making. Yet, in order properly to deal with the question, I would rephrase it slightly. I would rephrase it in terms of "decisional referents," a concept which I will explain below. Rephrased, the question now becomes: what determines the choice by a decision-maker of his decisional referents? And this question projects the further question: how can the decisional process be structured so as to improve the choice of decisional referents?

\section{A. Decisional Referents in General}

As I use the term, a decisional referent is whatever a decision-maker deems significant in deciding. ${ }^{26}$ Thus an official, or for that matter anyone else, who decides anything at all can be conceived as deciding with reference to one or more factors which are the important considerations underlying his choice among the options available to him. In most situations, the major factors determining the outcome of any decision are a statute, regulation, or other rule which specifies the basis for decision and the deciding official's view of the facts. In such cases the decisional referents are the applicable rule (or statute or regulation) and the official's view of the facts to which the rule applies. If the rule is sufficiently precise in its formulation and if there is no dispute as to the facts or if the facts have already been decided (as they may be in some cases in which an official reviews the decision of a subordinate), then the decision is preordained; there is no choice, no discretion. Once the deciding official has determined or obtained a view of the facts, his decisional referent is the applicable rule. If the rule is sufficiently clear, the rule itself determines the outcome: it-and the facts to which it is applied-are the sole decisional referents.

But rules are not the only kind of referents. A rule (apart from the set of facts

\footnotetext{
${ }^{38}$ The "referent" terminology has long been utilized by scholars. See, e.g., C. Ocden \& I. Rrararos, The MeAning of MEANing in (rst ed. 1923). In legal literature similar terminology is found, inter alia, in M. Gluckman, The Judictal Process anong the Barotse in Law and Wargare 59, 88 (P. Bohannan ed. I967). Cf. Gifford, supra note 15, at 420.
} 
to which it is applied) is a sole referent only where there are no conflicting rules and the terms of the rule speak precisely to the case at hand. Elsewhere than in these situations, referents other than the provisions of a single rule will come into play. The decision-maker necessarily must refer to matters outside of the rules themselves to resolve ambiguity in the rules. These nonrule referents may be guidelines, trade customs, social customs, analytical techniques, professional disciplines, prior practice, approaches shared or unshared with other persons, shared or unshared attitudes, values, understandings, the desires of superiors, political-party considerations-anything, in fact, which influences the decision-maker in his decision and to which he consciously adverts in deciding. This is an essential point of the present article: if we can broaden our focus from standards or rules to "referents" as just defined, we have a tool useful to lawyers interested in understanding, coping with, and improving administrative decision-making of both the formal and informal varieties.

\section{B. Judicial and Administrative Referents Compared}

When an appellate judge decides a question before him, his first look for decisional referents is to the statutes and to past decisions. A reference to what has gone before is likely to control, or to exert a heavy influence upon, the decision which he now must make. This search of the past may have contributed to the now-obsolescent conceptualization of the judge's function as one of "finding" a pre-existent law and of consequently underplaying the policy choices which the judge had to make. But even though judicial policy-making is now more clearly recognized, it is still circumscribed by the deference which the judge is expected to show the past. His opinions are expected to justify his present decisions largely in terms of these past referen's, previously enacted statutes and prior cases.

Despite the primary orientation of judicial decision-making towards the past, a judge's decisional referents are not exclusively past events. They could not be, otherwise he would never be able to overrule a prior decision. In any event, these past referents, that is, statutes and cases, may be inclusive and open-ended. In this latter event, we have seen that when the "rules" or prior cases are inconclusive, the decision-maker must attempt to resolve the ambiguity by making reference to factors outside of those rules or prior cases. Not infrequently, in resolving cases of decisional ambiguity, courts employ future-oriented referents. They are moved by the new states of affairs which will be brought about by the policy choices which they embody in their decisions. These potential states of affairs are thus "referents" which assist the judge in deciding and which make his decision intelligible. ${ }^{27}$

\footnotetext{
${ }^{27}$ In deciding new questions, courts are frequently moved by the results-or new states of affairswhich will be brought about by their decisions. These new states of affairs to be brought about may be perceived by the court as not only furthering justice for the parties before the court but as furthering justice in other cases which may arise in the future. Again, the effect of the present decision on future conduct is also taken into account as a decisional referent. Will a decision in favor of a destitute widow against an overreaching mortgagee discourage the granting of credit to widows of modest means? $C f$. R. Wasserstrom, The Jodicini Deciston I42-43 (Ig6I). Cases in which courts have overruled the traditional doctrine of charitable immunity furnish an example of courts utilizing as referents their
} 
In contrast to courts, agencies are often assigned a role which is openly recognized to be a more active one-and one which is less tied to the past. Their grants of power are sometimes made in statutory phrases which specifically refer to future -as yet unrealized--states of affairs which the agency is charged with bringing about. Thus the Civil Aeronautics Board is assigned the task of bringing about the development and prosperity of American air transportation. ${ }^{28}$ The Federal Power Commission, whose assigned tasks consist partly in conserving and promoting an adequate power supply for the nation, ${ }^{29}$ is perhaps typical of those agencies whose grants of power are phrased in present-oriented language but which are effectively charged with bringing about future states of affairs. Not only are agency charges phrased or uniderstood in terms of future goals; they are also phrased in language which is often quite vague. ${ }^{30}$ These two factors-the orientation toward the future and the vagueness of the terms themselves-suggest that the role which the agency is expected to play is an active one. Its attention is to be directed toward reaching a future state of affairs; and the lack of precise standards means that its efforts in reaching those goals are not to be circumscribed by the past in a manner analogous to the manner in which the past circumscribes the possibilities of judicial activism.

concern with present justice and a future, more desirable ordering of affairs. See, e.g., Bing v. Thunig, 2 N.Y.2d 653, I43 N.E.2d 3, I63 N.Y.S.2d 3 (1957); President \& Directors of Georgetown College v. Hughes, I30 F.2d 8 I0 (D.C. Cir. 1942). In these cases, that future ordering would be one in which charitable institutions would possess incentives to encourage care by their employees and to insure against the consequences of their negligent acts. Indeed, sometimes, as in the prospective overruling cases, the courts' holdings have been based upon referents which were primarily future states of affairs which their decisions would bring about and, in order to avoid injustice to the defendants before them who had shaped their conduct in reliance upon preexisting legal doctrine, the cases before them have been exempted from their holdings. Cf. Great North. Ry. v. Sunburst Oil \& Ref. Co., 287 U.S. 358 (1932).

${ }^{23} 49$ U.S.C. $\S \mathrm{I}_{302}$ (1970). Judge Friendly has pointed out that the delegated grant is one which would have implicitly incorporated the Motor Carrier Act scheme of regulation were it not for the large measure of uncertainty injected by a command in section 2 (d) that competition was to be fostered "to the extent necessary to assure the sound development of an air transportation system properly adapted to the needs of the foreign and domestic commerce of the United States, of the Postal Service, and of the national defense." H. Friendly, The Federal Administrative Agencies: The Nred FOR a BETTER DEFinition of StandaRds 75-76 ( 1962 ).

${ }^{20}$ At least as construed. FPC v. Union Elec. Co., 381 U.S. 90, 98-99 (1965); First Iowa HydroElec. Coop. v. FPC, 328 U.S. 152, 180 (1946). See also N.Y. Executtve LAw $\$ 294$ (McKinney Supp. I97I) (Division Against Discrimination charged with formulating policies designed to bring about a state of affairs in which discrimination is reduced).

${ }^{30}$ In the examples of the Civil Aeronauties Board and the Federal Power Commission, the referents supplied by the Congress are phrased in language which appears extremely vague when considered as a standard for decision in a case. But vagueness is a relative matter, and it may be that the statutorilysupplied referents, while aiding little in the decision of any particular case, yet may be helpful in the formulation of a general approach towards ultimate policy goals. Thus Davis and others have pointed out the error of expecting agency decisional standards to be supplied by the legislature and have suggested that recognition be given to the responsibility of the agency itself for the development of such standards. K. Davis, Discretionary Justice 49-5I (I969); Davis, A New Approach to Delegation, 36 U. Chr. I. Rev. 713 (1969); H. Friendey, The Federal Admintstrative AgenciesThe Need for a Betier Definition of Standapds I0-I8, 142-47 (Ig62). Compare, H. Friendly, silprat at ro, 163-75. This approach thus implicitly acknowledges that language vagueness is relative to the purpose for which that language is employed, and that statutory language which describes cnds or goals of administration is adequate for its purpose even though it is unworkable as a criterion for decision in an individual case. Cf. L. Wrttgenstein, Philosophrcal Investigations $\$ 88$, at $4 \mathrm{I}$ (G. Anscombe transl. 1953); I K. Davis, Administrative Law Treatise $\$ 2.03$, at 82 (1958). 
Operationally, this means that the major policy decisions of an agency which has been legislatively instructed to bring about a new state of affairs will be oriented primarily to the future rather than to the past. And since the agency has been left relatively free about the methods of arriving at the future goal which is itself described only imprecisely, the agency will require information about the subjects and subject-matter which it regulates so that it will be able to employ its freedom intelligently. It needs information about the probable consequences of various changes in the legal and regulatory environment which it is capable of bringing about. It will require knowledge about, or access to, analytical techniques or professional disciplines concerned with the subject matter of its regulation. In short, it is the task of the agency concerned to formulate as guides for its everyday operations decisional criteria and other decisional referents which will assist it in looking to the future. And these decisional referents, to be useful, must possess more content than the vaguely-phrased goals or directives contained in the statutory grant of power to the agency.

\section{Particular Kinds of Decisional Referents}

\section{Studies and Analyses}

Since it is the task of an agency to formulate usable decisional referents and since the agency requires knowledge to perform this task, it is critically important for the agency to learn about the subject-matter which it is regulating. One method for an agency to increase its knowledge about a problematic subject-matter is by studying it. ${ }^{31}$ The leader in large-scale, planned studies of regulated subject-matter has probably been the Securities and Exchange Commission. Its studies ${ }^{32}$ of the stock exchanges and of mutual funds have supplied a host of information useful to the Commission in making decisions, about major policy approaches. ${ }^{33}$ But in-

\footnotetext{
${ }^{31}$ In the Federal Communication Commission decisions allocating the electromagnetic spectrum among users, Commissioner Johnson has pointed out the Commission's lack of planning and its tendency to move in the direction of the greatest current pressure for use. Johnson, Tower of Babel: The Chaos in Radio Spectrum Utilization and Allocation, 35 LAw \& Contemp. Prob. 505 (1969). He noted that one of the greatest impediments to planning is the Commission's present ignorance about the "actual use" of radio spectrum in the various bands. Suggesting the desirability of a sophisticated decisional-referent system in which the net marginal social benefits of each use would be compared with benefits of alternative uses, Johnson saw a need for "data concerning actual use and economic value to the userand modern data processing procedures" Id. at 530. He asserted, in short, a primary need for knowledge-for information collection-and for processing that information into usable categories. Only when information is collected and made available in usable form can the Commission operate on a meaningful system of decisional referents and thereby routinize its decisions in a way which will further the goals achievement of which is its delegated responsibility.

${ }^{82}$ See SEC Report, Spectal Study of Securities Markets, H.R. Doc. No. 95, 88th Cong., Ist Sess. (1963); SEC, A Study of Mutual Funds, H.R. REP. No. 2274, 87th Cong., 2d Sess. (I962).

${ }^{33}$ Action by which major new policies are adopted necessarily utilizes different decisional referents from the more modest alternative form of agency action which proceeds incrementally along a path of small policy choices. In the latter case, information which facilitates each new step is gathered from prior experience. In the former case, information justifying a major new policy commitment is supplied from information sources, such as studies, other than the agency's prior experience. See, e.g., Iindblom, The Science of "Muddling Through," I9 PuB. AD. Rev. 79 (1959); Dror, Lindblom, Jones \& McCleery, Symposium on Governmental Decision Making, 24 PuB. Ad. Rev. I53 (1964). See also, A. ETzIon, ThB
} 
formation and the evaluations of information contained in those studies also furnish -referents for Commission decisions about matters of lesser import, including some cases involving the rights of particular parties. Dialogue within the Commission and its staff-and with outsiders when it occurs-will frequently make reference to material contained in these studies.

In the complaint-issuance decisions of the Federal Trade Commission, the studies and recommendations of its Economic Bureau seem, in the past, to have furnished important decisional referents. Thus, for example, the Economic Bureau's I955 Report on Corporate Mergers and Acquisitions ${ }^{34}$ seems to have been instrumental in the Commission's decision to issue complaints against a number of mergers in the dairy industry. ${ }^{35}$ By keeping informed about mergers and merger trends, the Bureáu can bring to the attention of the Commission information which may be crucial to the Commission's choice of respondents. The decisional processes of the Justice Department's Antitrust Division, which enforces the same antimerger statute, furnishes an instructive comparison of rule-referents with non-rule referents as significant decisional factors. The Antitrust Division's guidelines ${ }^{36}$-issued after prolonged study during the Turner administration of the Division-announce Division policy with respect to cases against which proceedings will be brought for -merger-law violations. These guidelines thus become decisional referents ${ }^{37}$ for the Division's complaint-issuance decisions. The specificity of the guidelines and the form in which they are couched makes them appear as rules. But the Trade Commission, in acting upon information and recommendations supplied by its Economic Bureau, is acting no less than the Justice Department upon the basis of decisional referents. Because the Commission's referents may not take the form of rules (and because Economic Bureau recommendations may not always be contained in published documents and hence sometimes may be less visible than the Department's guidelines) is no reason to ignore the essential similarity of the decisional processes of the two agencies. Dialogue within both agencies preliminary to a complaintissuance decision would properly address itself to the coverage of the case under consideration by the guidelines or the recommendations of the Economic Bureau and the extent to which the studies and information supplied by the latter indicated the propriety of a complaint-issuance. Officials advocating positions for and against

ACtrve SocIETY ch. I2 (Ig68) on a composite or so-called "mixed-scanning" approach to decisionmaking. Pursuit of a mixed-scanning approach would involve the use of both prior experience and in-depth studies as prime decisional referents.

86 FTC, Report on Corporate Mergers and Acquistitions (1955). See 3 Trade Reg. Rer. I jo,365 (FTC 1955).

${ }^{85}$ In the year subsequent to the issuance of the 1955 Report on Corporate Mergers and Acquisitions, the Commission issued anti-merger complaints against four concerns in the dairy industry, two of which were identified in the report as the first and third most active acquiring firms in the nation. See Beatrice Foods Co., 67 F.T.C. 473,704 (1965). See note 34 stipra.

"is i Trade Reg. Rep. If 4510 (Ig68).

${ }^{87}$ It has been suggested, however, that referents other than the guidelines or those factors expressly incorporated in the guidelines occasionally are employed by the Justice Department. See M. GnEEN, B. MOORE, JR. \& B. WASSERSTEIN, ThE CLOSED ENTERPRISE SYSTEM IIO-II (1972). 
complaint issuance would attempt to justify their respective positions largely in terms of the guidelines or the Bureau's recommendations and studies. And the decision to issue or not to issue a complaint would be made in large part upon a judgment of the extent to which the guidelines or the Bureau studies so indicated.

In addition to their role in complaint-issuance decisions, the studies of the Economic Bureau may form an important referent in the Commission's decisionmaking about other enforcement steps which it may take in the battle against anticompetitive mergers. Thus, the Bureau's study of vertical mergers in the cement industry led the Commission to institute rule-making proceedings to counter that trend, ${ }^{38}$ and the bureau's early study of the post-World War II merger movement was the Commission's main referent when it decided to ask Congress for legislation amending the original Clayton Act. ${ }^{39}$

\section{Specialized Disciplines}

Decisional referents, especially in connection with the decisions of routine issues, are often specialized bodies of knowledge. ${ }^{40}$ Thus in its enforcement of the RobinsonPatman Act, the Federal Trade Commission must evaluate cost-justification defenses raised by respondents. These defenses are generally based upon fixed and other cost allocations whose propriety turns upon the application of principles accepted by the accounting profession. This is to say that specialized knowledge of the accounting profession and its methods of analysis are proper referents in assessing the validity of an asserted cost-justification defense. Properly performed, the Commission's decisions upholding or rejecting asserted cost-justification defenses would utilize accounting concepts as referents, and those decisions would be motivated by and explainable in terms of accounting concepts. Similarly, the Federal Power Commission, in licensing proceedings, often makes use of knowledge and methods of analysis which belong to the economics and engineering professions. ${ }^{41}$ Prosecutorial decisions of the Justice Department and Federal Trade Commission use, or should use, the concepts and techniques of economic analysis as referents, ${ }^{42}$ and court decisions on antitrust questions have openly employed such concepts as referents in a number of cases. ${ }^{43}$ Decisions of various public utility commissions should employ as decisional referents, perhaps more frequently than they do, concepts drawn from economic analysis, such as marginal-cost pricing and consumer surplus. ${ }^{44}$

\footnotetext{
${ }^{88}$ See I Trade Reg. Rep. If 4520 (I967); 3 Trade Reg. Rep. If I0,I22 (I966).

80 FTC, Report on the Merger Movement: A Summary Report (I948).

${ }^{10} \mathrm{Cf}$. H. Simon, Administrative Behavior I69-70 (2d ed. x957).

1 See, e.g., Consolidated Edison Co., 33 F.P.C. 428 ( 1965 ).

4 See D. Gifford, A Legal and Economic Analysis of Section 2 (a) of the Robinson-Patman Act as Applied to Selected Forms of Business Organization (forthcoming).

${ }^{43}$ E.g., United States v. E. I. DuPont deNemours \& Co., 35I U.S. 377 (I956) (cross-elasticity of demand); United States v. Columbia Steel Corp., 334 U.S. 495 (I948) (cross-elasticity of production facilities).

"See note 102 infra. Compare, e.g., 3-B I. Sharfman, The Interstate Conmerce Commission 446-63 (1936). Cf. Hotelling, The General Welfare in Relation to Problems of Taxation and of Railwajp and Utility Rates, 6 ECONOMETRTCA 242 (1938).
} 


\section{Cost Analysis and Program Planning}

An assessement of the full resources of almost any regulatory agency in terms of manpower, budget, and perhaps special skills available to it and an assessment of the agency's delegated responsibilities would probably indicate that the agency lacks the resources to perform fully every function delegated to it. ${ }^{45}$ Such a situation calls upon the agency to structure a system of priorities and to allocate its resources on the basis of those priorities. ${ }^{46}$ Budget allocation upon the basis of a priority system created in this way would tend to promote resource allocation by functions or goals. ${ }^{47}$ And such a function or goal-oriented budget would, in turn, be best performed when the functions or goals were seen in their operations over an extended period, since it is only over an extended period that the budgetary claims of alternative programs competing for the agency's dollars can be assessed in their full light. This, in turn, suggests that budgetary decisions for the current year can' best be made when the agency's various programs are planned in advance for a several year period. When the agency's programs are planned in this fashion, the current year's budgetary decisions are made in the light of, and as a part of, the projected several year plan.

The present relevance of cost analysis and program planning ${ }^{48}$ is that once the agency's resources are allocated by program, many agency decisions and especially those with major budgetary impact will be reached in the light of their cost and the agency's program plan. Whether to proceed by rule or by adjudication in connection with particular kinds of undesirable conduct ${ }^{40}$ whether to proceed through precisely formulated rules issued in advance or to proceed by restructuring objectionable transactions, ${ }^{50}$ whether to issue complaints in certain categories of cases are all questions whose discussion within the agency and resolution by the agency will, or should, use cost analysis and the agency's programmed budget as referents. In order properly to decide a particular issue such as a complaint-issuance or effectively to argue within the agency for or against a particular resolution of such a decision, an agency official would have to be familiar with the grounds upon which that decision should or would be reached. When the grounds are program cost and program-budget allocations, he would need to know the content of the program-

${ }^{45}$ See, e.g., Elman, Administrative Reform of the Federal Trade Commission, 59 Gro. L.J. 777 (197r); Dixon, Program Planning at the Federal Trade Commission, 19 Ao. L. Rev. 408 (1967).

${ }^{16}$ See, e.g., Smithies, Conceptual Framework for the Program Budget, in Procrum Budoetino 2, 19 (D. Novick ed. 1964-65). Cf. Developments in the Law-Deceptive Advertising, 80 Harv. L. REv. 1005, rog9-IIor (I967); Note, Program Budgeting for Police Departments, 76 YALE L.J. 822 (1967).

${ }^{17}$ Smithies, supra note 46 .

${ }^{4}$ By relating costs to functions, the way is paved for the exercise of a cost-benefit type of control over the priorities accorded to each function. This, in turn, facilitates advance planning of the agency's various functions. Comparative judgments can now be made about how much emphasis is to be placed upon each function in the light of its costs and alternative uses for the money involved. Cf. Dixon, sulpra note 45 . See generally notes $45 \& 46$.

49 See, e.g., FTC, Trade Regulation Rule for the Prevention of Unfatr or Deceptive Advertisino and Labeling of Ctgarettes in Relation to the Health hizards of Smokino and Accompanyino Statement of Basts and Purpose of Rule I37 (I964).

${ }^{50}$ On post hoc restructuring of objectionable transactions, see Gifford, supra note 15, at 440-42. 
budget allocation decisions in order, first, to evaluate for himself which way such a decision should go and, then, when he himself is not the decision-maker, to make a presentation which is meaningful to the officials who are the decision-makers. $\mathrm{He}$ would have to be able to explain, first, to himself and, second, in cases in which he participates in the decisional process as a subordinate or is otherwise accountable to others, how the decision he is supporting meets the terms or rationale of those budgeting allocations. And, while the budgeting decisions might not be the only relevant factor, an advocate of a position would have to connect his arguments with those factors in order to be convincing when they are significant or major elements in the decisional process.

\section{The Significance of Decisional Referents}

The concept of a decisional referent as a factor consciously taken into account by a decision-maker is an old one. Statutes listing factors to be considered and weighed by agency decision-makers have not been infrequent in the past. ${ }^{51}$ Nor has it been unusual for agencies themselves to promulgate lists of factors which they assert are the major ones which they consider in' deciding cases. ${ }^{\mathbf{2}}$ Moreover, judicial review of agency action for arbitrariness or abuse of discretion proceeds, at least at times, on the basis of an analysis implicitly in terms of the appropriateness or inappropriateness of the decisional referents employed by the agency. ${ }^{53}$ Jaffe's analysis of judicial review, for example, explicitly embodies the concept of decisional referents. 54

Yet, despite its familiarity, the close relationship between rules and all decisional referents ${ }^{65}$ has gone largely unexplored and perhaps has been recognized only superficially by many observers of administrative behavior. There has been a continuing outcry against secret administrative rules, ${ }^{56}$ but little outcry against secret decisional referents. In his recent book, Davis stretches the concept of "rules" to embody advisory opinions, including advisory opinions on hypothetical facts, ${ }^{57}$ and in this manner he hopes both to encourage agencies to disclose their policies and to encourage them to act consistently (by complying with the policies so disclosed). But even Davis fails to focus upon the need to conceptualize agency decisional processes in terms of

\footnotetext{
${ }^{51}$ See, e.g., TENN. CODE ANN. $\$$ 56-602 (repl. 1968) (listing factors to be considered by state insurance commissioner in approving or rejecting applications for rate increases). See Long v. National Bureau of Casualty Underwriters, 209 Tenn. 435, 442-46, 354 S.W.2d 255, 259-60 (I96r).

${ }^{62}$ WHDH, Inc., 22 F.C.C. 767 (1957).

Bs See text accompanying notes 75-82 infra.

E4 L. JafFe, Judicial Controt of Administrative Action i8i (ig65) ("nearly all powers to act. however numerous and broad the considerations relevant to choice, exclude and deny the legality of other elements as factors of choice.")

${ }^{58}$ See text accompanying note 26 supra.

${ }^{60}$ E.g., U.S. Comm'n on Organization of the Executive Branch of the Gov't, Report of the Tast Force on Iegal Service and Procedure 150 (1955); Attorney General's Committee on Administrative Procedure, Finat Report, S. Doc. No. 8, 77th Cong., ist Sess. 29 (I94I). Cf. Newman, Government and Ignorance-A Progress Report on Publication of Federal Regulations, 63 HARv. L. REv. 929, 936-37 (1950).

57 K. Davis, Discretionary Justice $59-64$ (1969).
} 
decisional referents. By so doing we would see the blurring of rules into other decisional referents-compare "rules" with "guidelines," for example-and the need to apply many of the approaches which we now apply to rules to the latter as well. More precisely, in dealing with any government official, lawyers would be more conscious of their need to learn the official's major decisional referents in order to carry on an effective dialogue or to present their cases in their most favorable light; they would be more conscious of their need to address their arguments to those referents, or to cast them in terms of those referents; and they would be more conscious of their need to seek out the particular supervisory official who has power to change a referent or to waive its application.

Let me make these points in a more concrete fashion. Suppose, for example, that one decisional referent of a public service commission in setting freight rates consists in the application of "the usual and ordinary ratio of distribution of freight charges according to the value of the product carried." ${ }^{58}$ In rate negotiations with the commission-to say nothing of his conduct in a formal rate proceedingcounsel for a carrier would be handicapped to the extent that he was ignorant of the use of a ratio as a tool in the setting of a freight rate and would be further handicapped if he did not know what the "usual and ordinary" ratio was. Suppose, for instance, that good reasons could be shown why the usual and ordinary ratio ought not to be applied to the rates for the particular commodity in question. An attorney ignorant of the decisional referent would never make that showing. But it will be said that counsel for a carrier would have learned about that referent and its significance from his experience and associations with others involved in rate regulation. Maybe. But would counsel for a firm engaged in large but occasional shipments? Would his greater distance from rate regulation as a central concern deprive him of knowledge of referents which would be critical in rate negotiations with the commission or with a carrier?

Let us consider another example. Is a lawyer for an applicant to the Small Business Administration always aware of the fact that a decisional referent for the Administration is the applicant's record with the Federal Bureau of Investigation and with the House Un-American Activities Committee? ${ }^{50}$ If not, might not his client's application be rejected on a ground which the lawyer could have met had he been aware of it? I am thinking here, of course, of a case in which the client's activities which brought him to the attention of these investigating bodies could be shown by the lawyer to be completely innocuous. Perhaps, also, the lawyer might be able to persuade the Small Business Administration that the use of such a referent was improper. But, again, he could never do this so long as he remained unaware of the referent.

\footnotetext{
${ }^{58}$ Chicago \& N.W. Ry. v. Railroad Comm'n, 156 Wis. 47, 56, r45 N.W. 216,218 (19r4).

${ }^{80}$ House Comm. on Government Operations, 85 th Cong., ist Sess., SuRvey and Study op Administrative Organization, Procedure and Practice in the Federal Agenctes 20it (Comm. Print I959).
} 
An analysis in terms of rules, as commonly understood, is not helpful in either of these situations if we assume (I) that the public service commission does not always apply a ratio in its calculations nor in those cases in which a ratio is employed is the ratio always the same, and (2) that the Small Business Administration does not always reject applicants whose names appear in the investigatory files of the FBI and the House Committee but that it takes such a factor into consideration as a negative element in deciding whether to grant an application. A requirement of rule disclosure would not help. And an attorney who was conscious of a need to master the agency's rules and to present his case in terms of those rules would still be likely to miss the point. Here Davis's concept of reconceptualizing the meaning of a "rule" to include an advisory opinion on hypothetical facts might be of some assistance, especially in the example of the public service commission. If the agencies accepted Davis's suggestion about reconceptualizing rules and if they then formulated advisory opinions on hypothetical facts and promulgated those opinions, lawyers in the first example might receive the information they require to present their cases adequately. But in the second example, where factors are weighed which are not deemed controlling, even the agency which adopted the suggestion to promulgate hypothetical advisory opinions might not be led to inform interested and affected persons about the manner in which it reaches its decisions, namely, that in deciding, it weighs in the balance investigators' files on criminal and subversive behavior.

More to the point, however, is that Davis's suggestion is one directed at agencies. It is an admonition to officials and to agencies to disclose their standards for decision, however undeveloped those standards may be. The suggestion in this section of the article is that the concept of a decisional referent is useful not only to agencies thinking about disclosing their decisional standards but also to lawyers attempting to cope with a bureaucracy. By focusing upon the decisional referents of the officials with whom he is dealing, the lawyer will be better prepared-to look for and to discover relevant decisional referents, to present his case in its most favorable light, to negotiate effectively, to appeal within the administrative hierarchy the application of improper referents or the improper application of generally proper referents. He will be better equipped to assess the level in the administrative hierarchy at which he can find the relief he requires. Normally, for example, a lower-echelon official will be unable to respond to an argument which attacks the basic validity of a referent widely used in his department. Yet a presentation which undercuts the validity of such a referent may gain the time and attention of an upper-echelon official who does have power to grant relief. And-here the analogy between rule and nonrule referents is apt-the very widespread use of the referent within the department may make the challenge sufficiently important to merit that official's attention. Again, the analogy between rule and nonrule referents indicates that the lawyer who seeks the nonapplicability of a nonrule referent to his case will have a better chance of succeeding if he can show why the nonapplication which he seeks will have very little consequence for the overall administrative routine-that the uniqueness of his case 
would enable a consistent administration to grant the relief which he seeks without affecting the disposition of a significant number of other cases. But the concept is not limited in its usefulness to the practitioner. An analysis in terms of decisional referents may uncover, or direct attention upon, other aspects of administrative action which have been unnoticed or neglected. The beginnings of such an attempt are contained in this article.

\section{III}

\section{Human Interaction and the Choice of Decisional Referents}

The process of interaction among the participants in a decisional process seems likely to influence the choice, by each participant, of the referents which will underlie his decisions. As more fully developed below, this interaction process seems to have both dynamic and stabilizing dimensions in the sense that it may affect the information upon which each decision-maker acts and it may reenforce a natural inclination on the part of each decision-maker to repeat prior solutions.

In situations in which officials employ rules supplied to them by an external authority to reach solutions anticipated in the rules and described with precision in those rules, the impact of personal interaction among the participants in the decisional process is minimized. (Of course, even here the interaction between the decision-maker(s) and a claimant or his representative and witnesses may significantly affect the content of the decision.) When an external authority supplies the deciding officials with their major decisional referents (rules, studies, budgetary allocations, and so on), interaction among the decision-makers is not needed to ensure that those externally-supplied referents are employed by them. But interaction may have a significant impact upon the weights accorded to each referent and in the selection and development of new decisional referents.

\section{A. Dynamic Aspects of Human Interaction in Decisional Processes}

The dynamic dimension of human interaction comes into play when a decisionmaker or other participant in a decisional process (such as an advisor) alters his approach as a result of his contact with another person. Such a situation would occur when a decision-maker's contact with another person brings him new information or acquaints him with new ways of perceiving the matter before him or makes him aware of criticism of his own position to which he had previously not been exposed. $^{60}$ Thus, for example, in a program ${ }^{61}$ utilized by the federal district court judges for the Eastern District of Michigan, judges meet in groups of three to discuss the sentences which each intends to impose in cases coming before him. Each judge reports to the other two on a number of cases, describes the relevant factors as he sees them, and states his own evaluation and the sentence which he has initially decided upon. Each of the other two judges then states his own perceptions of those

\footnotetext{
${ }^{60}$ Indeed, the performance of this function of collecting information and criticisms has always becn perceived as the primary goal of agency rule-making proceedings.

${ }^{61}$ See Levin, Toward a More Enlightened Sentencing Procedure, 45 NEB. L. Rev. 499 (1966).
} 
cases and of the relevant factors in them, his evaluations, and the sentences which he would impose. The procedure thus exposes each judge to insights and to criticisms of his own positions of which he otherwise would have been unaware. In that sense, the final sentencing decision of each judge is better informed. The exposure of his decision and the reasoning behind it to his colleagues also influences each judge "to examine his own prejudices and motivations underlying his conclusions." ${ }^{122}$ The procedure thus is an aid to each judge in uncovering factors personal to himself which ought not to influence his decision, but which might do so in a manner hidden even to himself. In this sense, the procedure seems useful in helping each decision to reflect the conscious choice of the deciding judge. The procedure does not divest the assigned judge of the responsibility for deciding. Indeed, as noted, it heightens that responsibility. It enables each judge assigned to render a sentencing decision to exercise that responsibility in a more informed manner. The procedure thus encourages self-criticism and openness to change. It also appears to have influenced a significant number of judges to rethink and to change the sentencing decision which they had initially reached. Judge Levin informs us that the Sentencing Council has tended

to create a consensus among the judges on which factors are most relevant in sentencing and the weight to be accorded to each of them.... The factors presently considered most significant are the offender's prior record, family responsibility, work record, the likelihood that the defendant will respond to probation, and whether custody is required for either rehabilitation or for the protection of the public.83

He thus describes a situation in which interaction among the judges has produced a growth process in which the original set of decisional referents of each participant has developed and has been modified in the light of the insights, comments, experiences, and criticisms of the others. The result has been a developing convergence toward a commonly held set of referents. ${ }^{64}$

In a very different context, a similar process may be at work in the Office of the General Counsel of the National Labor Relations Board. That office supervises the enforcement of the National Labor-Management Relations Act by the several Regional Directors located throughout the nation. New policy questions may arise within the General Counsel's office or they may be referred there by a Regional Director who seeks advice on a novel issue. Such new policy questions are usually resolved in that office in a meeting of several officials called an "agenda."

\footnotetext{
${ }^{02}$ Id. at 505 .

${ }^{63} \mathrm{Id}$.

at Cf. Carp, The Scope and Function of Intra-Circuit Judicial Communication: A Case Study of the Etghth Circuit, 6 IAw \& Soc'y REv. 405, 407 (1972). Carp hypothesizes that "differences in the judicial behavior of U.S. trial judges from circuit to circuit persist because for these judges the circuit is a semi-closed system, a nearly self-contained organizational unit within which there is considerable interaction among its members and almost no interaction between members of one unit (circuit) and another." See also id, at 42I-22.

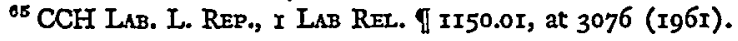


ticipating in the agenda are a staff attorney who has researched the problem under consideration (and who has uncovered the relevant prior advice which the office has rendered in other cases), his supervisor, the Assistant General Counsel in Charge of Advice, the Associate Branch Chief, the Assistant General Counsel in Charge of District Court Litigation, the Special Assistant to the General Counsel, and, in some instances, the Associate General Counsel in Charge of the Division of Litigation. The agenda device brings about the exposure of each of the several participating officials to the insights and criticisms of the others. As in the case of the Sentencing Council, it is possible that such exposure would induce a participant to alter the position which he originally espoused. Indeed, the resemblance of the agenda device to committee decision-making appears close. And it has been at least my own experience that the insights and criticisms of other committee members will persuade me to reevaluate and to modify or to alter my original position. In any event, the decision reached by the agenda is informed by the considerations brought out in the research of the staff attorney and in the group discussion of the agenda participants. Since most of the participating officials are involved in various aspects of enforcement administration, each can draw upon his own special area of administration for insights on the ramifications of the new policy positions which the office might adopt. ${ }^{66}$

In the two examples, the agenda is more formally a group or collective decisionmaking or decision-recommending body ${ }^{67}$ than the Sentencing Council, which explicitly recognizes that decision-making remains with each of the participating judges acting individually. Yet in each example the structure of interaction is designed to expose the participants to the insights, attitudes, experiences, and information of the others. When such exposure does occur, it is not unlikely that an individual's position will be affected. ${ }^{68}$ By contrast, and as a third example of agency decisional processes, the United States Parole Board, at least in the past, never met in group deliberations about individual cases. ${ }^{69}$ It thus seems to have structured its operations in just the kind of way which would avoid the interaction process described in connection with the Sentencing Council and the General Counsel's agendas. As we have been informed by Judge Levin, ${ }^{70}$ the effects of the interaction process upon individual participants in the Sentencing Council have been dramatic. In the agenda, we might expect that similar dramatic shifts would occur in the case of individuals who are newly appointed to agenda positions and who previously have not been exposed in a prolonged manner to some significant factors or attitudes which recur in agenda deliberations. As an institution, however, we might expect that the agenda would be relatively stable in its collective approaches, because its

\footnotetext{
${ }^{68}$ Cf. J. Galbraith, The New Industrial State 6I-67 (Ig67).

B7 The agenda's decisions are recommendations to the General Counsel.

${ }^{68}$ Levin reported that a change in the proposed decisions of each participating judge occurred at least eight times in 1965 . Levin, supra note $6 \mathrm{r}$, at 507.

${ }^{80} \mathrm{~K}$. Davis, stipra note 57 , at 126.

${ }^{70}$ Levin, supra note $6 \mathrm{r}$, at 505-06, 511-12.
} 
relatively stable membership should produce a relatively constant mix of attitudes and information in the agenda dialogues. Indeed, as we have seen, such an ultimate stability -in the form of a group consensus-seems to be developing in the Sentencing Council. ${ }^{71}$ Nevertheless, this stabilizing quality ought not to obscure the fact that the Council and the agenda-in contrast to the procedures of the Parole Boardare designed to bring to the attention of the participants factors, that is, decisional referents, of which they were previously unaware and, in that light, to promote changes of individual positions. Implicit in such a statement is the suggestion that a broader exposure of the participants might, by acquainting them with additional relevant decisional factors, affect their decisions even more. The potential for administrative dynamism in this suggestion is explored more fully in the next section.

\section{B. The Stabilizing Aspects}

When a decision-maker decides, not in isolation, but in the presence of one or more other people who are aware of the positions which he is taking, he is acting in a significantly different context from the official who acts in isolation. In the non-isolated situation, the deciding official is exposed to pressure to justify departures from his own prior practice not only to himself but, since his earlier decisions have been seen by other officials who will observe his present decisions, to other officials as well. Moreover, not only may the decision itself be observed by other officials, but the considerations underlying those decisions-the decisional referents-may be exposed to the gaze of those officials. In these circumstances, the official who feels a need to justify a departure from his prior practice must explain his justification in the light of the decisional referents used by him in his earlier decisions. He must explain how these referents justify apparent. departure or, alternatively, if new or different referents are used to justify his present decision, why these latter referents are appropriate for present use but were inappropriate for use in the earlier decisions.

It should be observed that the officials whose presence induces the decision-maker to explain his departures from his prior practice need not be superiors. They may be colleagues or even subordinates. The important factor is that the deciding officials act, and have acted, in the presence of these same individuals and that those same individuals are aware of the decisions which are being made and of the factors underlying them. Thus, for example, decisions about remitting or mitigating forfeitures are currently made in the Justice Department's Bureau of Narcotics and Dangerous Drugs by two officials and reviewed by their superior. ${ }^{72}$ The two officials

\footnotetext{
${ }^{71}$ Id. at 505 , quoted in text accompanying note 63 supra.

${ }^{72}$ This description of the Justice Department's decisional structure for mitigation and remission cases is different from that which was described by Davis and to which reference was made earlier. See text at note 6 supra. Davis, supra note 57, at I09-II. The present description is drawn from my own work on behalf of the Administrative Conference of the United States in the late 1960's while Davis's description is that of the Justice Department's organization of the early and mid-rg6o's. See Gifford, Remission and Mitigation of Forfeitures in the Justice Department, in I RECOMMENDATIONS AND REPORTS of the AdMinistrative Conference of the Untred States 697 (Jan. 8, ig68-June 30, I970).
} 
share the same office, and frequently discuss their decisions with each other. They spend about a quarter of their time making remission decisions and each has been involved in this work for a number of years. In such circumstances, it is apparent that decisional criteria are worked out by the two officials together; that the hard cases are discussed by each with the other and with their superior; that common approaches worked out together will probably be followed by each of them. But more is apparent also. It is apparent that when either of the two is tempted to depart from the commonly worked-out path, he feels a pressure to justify any departure, not only to himself, but also to his colleague. Initially, the pressure is not that which is exerted by any formal rule-or any binding obligation. Rather, it is a pressure which arises from human interaction. Having once explained what I thought was a well-considered position to my colleagues, I feel uncomfortable in deviating from that position in future cases without explaining the reasons for my departure to those colleagues.

The preceding discussion is not meant to suggest that a responsible person will refuse to change his approach in the light of new factors brought to his attention. ${ }^{73}$ It is meant to suggest that when such a person does change he may feel called upon to justify that apparent deviation. Moreover, as the Sentencing Council experience seems to illustrate, a person may feel pressure to justify (to himself and to others) not only deviations from his prior patterns of action, but also to justify (to himself and to others) deviations from norms or other decisional referents shared by other members of the group in which he is acting. ${ }^{74}$

\section{IV}

\section{Identifying Permissible and Impermissible Referents}

\section{A. "Arbitrary" Administrative Action as the Use of Impermissible Referents}

It is hornbook law that agency action which is "arbitrary" or "capricious" generally may be set aside by the courts. ${ }^{75}$ Sometimes the term "arbitrary" has been equated by the courts with "irrational." But this cannot really be the meaning of "arbitrary" when it is used in connection with judicial disapproval of agency action. It cannot, because very little governmental or other action is really irrational in the normal meaning of that term. Indeed, even in the case of an official who awards a contract to a firm which has paid him a bribe (rather than on the basis of a judgment about the quality of the contractor's work), the contract award would probably be set aside as arbitrary. But the official was not acting irrationally at all; he knew what he wanted and used effective means to realize that end. A second meaning of "arbitrary" is "based on or subject to individual judgment or dis-

\footnotetext{
${ }^{73}$ See, e.g., Levin, supra note $6 \mathrm{I}$, at 507 .

74 Id. at 505 .

${ }^{75}$ See 2 F. COOper, State Administrattve LAw 758-65 (1965).

${ }^{76}$ See R. Benjamin, Admintstrattve adjudication in the State of New York 346 (1942). C 2 F. COOPER, supra note 75 , at 764 .
} 
cretion."77 But, again, this meaning cannot explain its use by the courts in describing agency action which ought to be set aside: much agency action is properly a matter of judgment (that is, discretionary in Dworkin's first, weak sense), ${ }^{78}$ and some agency action is explicitly made discretionary in the strong sense by the legislature. And such authorized discretionary action is not subject to judicial invalidation.

The significant part of the latter definition, rather, is the adjective "individual" modifying "judgment." "Individual" throws light upon the equation of "arbitrary" with "irrational" in the former usage. When a characterization of arbitrariness is used by a court as a justification for invalidating administrative action, the court's objection to that action is not that one or more individuals have utilized their judgment, but rather that in utilizing their judgment their decisional referents were their own in a context where the legal system within which they operated demanded the use of other referents; in other words, their referents were "individual" rather than "system" ones where the two conflicted: the contract was awarded on the basis of a bribe rather than on the basis of the quality of the contractor's work. A similar explanation is available for the usage of the term "irrational": a test of rationality is the adaptation' of means to a desired end or goal. ${ }^{79}$ When action is characterized as irrational in a legal context, it means that the action is not designed to reach the goals of the legal system, that it is designed to reach other, "individual" goals instead. In short, the test of arbitrariness has largely been whether the agency decision was based upon permissible or impermissible referents. And the test of the permissibility of the referents employed has been their relation to a recognized end or goal of administration.

This perception of arbitrary versus rational action-a largely traditional perception-has developmental possibilities that embrace the whole of administrative action. If it is correct, as suggested, ${ }^{80}$ to explain the difference between "arbitrary" and "rational" action as action based, respectively, upon "impermissible" and "permissible" referents, ${ }^{\text {s1 }}$ then we can use this analysis to probe further into both formal and informal decision-making. Remembering that judicial invalidation of agency action characterized as arbitrary has depended upon the exposure of the underlying decisional referents to the court which makes the judgment about the permissibility

\footnotetext{
"7 American Heritage Dictionart.

${ }^{78}$ See Dworkin, supra note 4 , at 32 , and accompanying text.

70 See, e.g., H. Simon, Administrative Befinvior 76-77 ( $2 \mathrm{~d}$ ed. 1957). Compare Davis's use of the term "irrational" in Discrettonary Justice $9 \mathrm{r}$ ( $\mathrm{x} 969$ ) ("cases are often selected for enforcement on irrational grounds").

${ }^{80}$ See text accompanying notes $75-79$ supra.

${ }^{82}$ A similar approach is followed in L. JafFe, Judicial Control of Administrative Action i8I (r965). Cf. Friendly, Chenery Revisited: Reflections on Reversal and Remand of Administrative Orders, I969 DUKE L.J. I99, 2 I1 1 - 2 . Friendly properly distinguishes between incorrect reasons and findings, id. at 205, while pointing out that either incorrect reasons or incorrect findings are a basis for court reversal of administrative action. In the text I have generally utilized the term "decisional referent" in preference to "reasons" because the term "referent," while sometimes including "reasons," is broader and includes motives and matters which Davis might characterize as "legislative facts" or "adjudicative facts" present or absent from the record. I K. Davis, Adanmistrattve LAW Treatise $\$ 7.02$ (I958).
} 
of the referent, we might ask whether exposure ${ }^{82}$ of the underlying decisional referents-to persons other than the decision makers-could become a prime tool in preserving or changing decisional referents and their contents.

\section{B. The Limitations of Judicial Review}

Before exploring referent exposure further, let us, for purposes of perspective, focus upon the limitations of judicial review for administrative arbitrariness. It is obviously true that a court cannot deem a referent employed by an administrator to be "impermissible" unless the court can perceive the referent and judge its use to be in conflict with the goals of the statute which the agency is administering. Two factors thus are necessary: first, exposure of the referent to the court and, second, a court evaluation that use of the referent in question is inconsistent with statutory goals. Yet the second factor itself requires further analysis: an analysis which distinguishes between (a) a judicial judgment whether the agency employed the referent in question in a good-faith attempt to reach statutory goals and $(b)$ a court evaluation of the adequacy of the referent for the purposes for which it was used by the agency. A court will not be reluctant to strike down agency action which employed a referent whose use was inconsistent with statutory goals. But those courts which are sensitive to a need for a functional division of labor between courts and agencies will inquire into the adequacy of the agency's decisional referents for the purposes for which they were employed, if at all, only with trepidation. It would be too much to say that courts will not substitute their own referents for those employed by the agency whose action they are reviewing. They will and do when the issues are sufficiently important. It remains true, however, that an area surrounding the routine, the everyday operations of the agency, is an area which courts are reluctant to enter. Within this area, judicial inquiry would normally be perceived as an unwarranted interference in agency policy-making. ${ }^{83}$

The last distinction made in the preceding paragraph is somewhat reminiscent of one employed by Herbert Simon in a discussion of administrative behavior ${ }^{84}$ Simon's distinction is between "subjective" and "objective" rationality. A decision is subjectively rational if it "maximizes attainment relative to the actual knowledge of the subject"; it is objectively rational "if in fact it is the correct behavior for maximizing given values in a given situation." any, decisions can be consciously objectively rational because full information is rarely available when a decision must be made. But, since some decisions can be more accurately informed than others, it is perhaps acceptable to say that de-

\footnotetext{
${ }^{82}$ The cutting edge of the administrative "openness" for which Davis has long argued, K. Davis, Discretionary Justice 97-14I (1969); K. Davis, I AdMinistrative Law Treatise $\$$ 4.I4 (Supp. 1965), $\$ \$ 4.14-4.18$ (Supp. I970), consists in exposure of administrative decisions to persons who bave the competence and time to evaluate those decisions.

${ }^{83} \mathrm{Cf}$. L. JAFFE, supra note 81, at $\mathrm{x} 82$.

${ }^{84} \mathrm{H}$. Simon, Administrative Behavior 76 (2d ed. 1957).

${ }^{85}$ Id.
} 
cisions can differ in the degree to which they approach an ideal of objective rationality. So stated, Simon's distinction is useful to our present analysis of decisional processes: judicial review is concerned with the subjective rationality of decision-making. Exposure, as I will argue below, is capable of improving the "objective" rationality of agency decision-making.

\section{Exposure of Agency Referents as a Force for Increasing the Objective} Rationality of Administrative Decision-Making

Now let us direct our focus away from judicial review and toward other ways, including less formal ways, of controlling agency action. As we have already observed in connection with the Sentencing Council, ${ }^{86}$ the exposure of an official's decisional referents to the critical scrutiny of others may disclose the inadequacy of those referents and create pressures to bring about their change. This type of constraint upon agency action will tend not to be limited-as is judicial review-to overseeing the good faith of agency policy choices. Rather, exposure of the agency's decisional referents to the critical scrutiny of others possesses a potential for promoting the selection of decisional referents which are adequate for the purposes for which they are employed, that is, for improving the degree of objective rationality of agency decisions.

Earlier we asked whether exposure of decisional referents to superiors or to subordinates or to colleagues would exert pressures upon a decision-maker to act consistently. ${ }^{87}$ Now we ask whether exposure of decisional referents to superiors or to subordinates or to colleagues or to others will generate pressures to improve the choice of substance of the referents themselves. In support of an affirmative answer to this question is the point that the exposure of decisional referents to others gives those others the opportunity to examine those referents critically. When, for example, a colleague knowledgeable in matters of economic theory observes a trial attorney in the Federal Trade Commission utilize as a decisional referent a misconception of pricing theory, ${ }^{88}$ he may be able to explain to the trial attorney the correct conception. In such event the trial attorney acquires the knowledge which he needs to improve the quality of a decisional referent. The more the trial attorney's referent is exposed to numbers of observers with some degree of sophistication in economic theory and the more those persons strive to point out to him his erroneous conception, the more difficult will it be for the attorney to persist in the use of his original referent. Again, the exposure, if only to his superior, of the set of rules used by the official exercising remission power ${ }^{89}$ would bring that set of decisional referents under a new source of critical scrutiny, and, in so doing, the

\footnotetext{
${ }^{80}$ See text accompanying notes $60-64$ supra.

${ }^{87}$ See text accompanying notes 72-74 supra.

${ }^{88}$ Cf. Forster Mfg. Co., 62 F.T.C. 856, 902 (1963) vacated and remanded, 335 F.2d 47 (xst Cir. 1964). Compare Atlas Bldg. Prod. Co. v. Diamond Block \& Gravel Co., 269 F.2d 950, 956 (Ioth Cir. 1959), cert. denied, 363 U.S. 843 (1960).

${ }^{80}$ See text accompanying notes 6-I I supra.
} 
content of those rules might be affected. Exposure of those rules to a wider circle, including those affected by them-such as, for example, banks and other credit institutions which hold large numbers of security interests in automobiles ${ }^{00}$-would subject those rules to a wider range of critical scrutiny which, in turn, again might affect their content.

Exposure, thus, is a relative rather than an all-or-nothing matter. Exposure of referents employed by an official to other officials working in close proximity to him may exert pressure upon him to employ referents which can withstand their critical scrutiny. But exposure of those referents to larger circles of officials within the agency structure (who have time and motivation to see those referents and to reflect upon the propriety of their use) ${ }^{91}$ and to persons outside of the agency structure (including persons adversely affected by the use of those referents who are likely to have both the time and the motivation to reflect upon the propriety of their use) ${ }^{02}$ will subject them to increased amounts of scrutiny. And the potential or resulting criticisms may affect the kinds of referents which will be employed.

'The significance which attaches to exposure thus turns upon the ability and the motivation of the onlookers to criticize the referents and to convey that criticism to the decision-maker. Besides the degree of the onlooker's competence to evaluate the referent's content, his ability to make meaningful criticisms of its use depends upon his familiarity with the decisional content in which the referent is employed, ${ }^{03}$ the time which he has to devote to criticism ${ }^{94}$ and to communication of that criticism, and the ease with which that criticism can be conveyed.95

\section{Implications for the Decisional Structure}

We have concluded that the exposure of referents (including non-rule referents) to increased critical scrutiny has potential for improving the quality of decisions, that is, for increasing their objective rationality. The publication of the Securities and Exchange Commission studies ${ }^{96}$ exposes their content to experts and others knowledgeable in the securities field and thereby facilitates the correction of errors in those studies. If, and to the extent that, substantial errors are shown to exist in them, the

\footnotetext{
${ }^{\circ 0}$ Gifford, supra note 72.

${ }^{01}$ Exposure to others is not alone sufficient. Those others must understand the context in which the referent is employed and possess the requisite time and motivation to make a judgment about the propriety of its use. The considerations raised here are analogous to those which the courts have raised in conjunction with the grant of judicial and administrative standing to so-called "public-interest" representatives. See text accompanying notes ro6-r75 infra.

92 The adverse effects may themselves be helpful in engendering the motivation. See text accompanying note II3 infra.

${ }^{98}$ That is to say, familiarity with a particular body of specialized knowledge (such as engineering, economic theory, or regulatory law) is requisite to understanding the context in which the referent is employed.

ot Cf. J. Marsh \& H. Simon, Organizations i6g (I958).

${ }^{98}$ In order to complete the feedback loop, the understanding observer must be able to communicate his criticism. But the greater the impediments to his doing so (such as access barricrs to the person whose acts are being criticized), the greater his motivation must be to overcome those impediments.

${ }^{98}$ See note 32 supra.
} 
Commission and its officials will learn that some of the contents of those reports cannot be accepted as accurate, and, hence, are to that extent improper referents for decision. By contrast, the reports of the Federal Trade Commission's economic bureau-especially those which focus upon assertedly dangerously developing anticompetitive situations-are not always public documents. Errors or deficiencies in those reports, therefore, cannot so easily be uncovered, and the Commission and its officials may use these reports as referents in ignorance of their defects. Examples of administrative secrecy protecting a referent-system from critical scrutiny abound. ${ }^{97}$ Thus, for example, an early study of the then New York State Commission Against Discrimination complained that the Commission's work could not be accurately evaluated because of the secrecy shrouding its settlement policies and the criteria underlying them. ${ }^{88}$

Again, the handling of the Federal Trade Commission of cost-justification defenses by firms charged with Robinson-Patman violations has been criticized for demanding precision which cost-accounting principles cannot supply. I make no attempt here to determine the extent to which this criticism is valid or the extent to which the Commission's insistence upon precision is necessary to prevent businessmen from abusing the permission which the statute accords them. ${ }^{99}$ The relevant point is that the best decisions about the cost-justification defense would be made when the decisional process was designed to include professional accounting advice. Auerbach's study of Commission organization was critical of the Commission on just that point. He asserted that by making the Commission's accounting division a component of the bureau of restraint of trade, the Commission tended to deprive itself and its hearing officers of accounting advice which is not proffered from an adversary source. ${ }^{100}$ This, of course, does not have to occur, even under the existing organizational structure, and the Commission has full access to accounting advice on questions of complaint issuance and settlement. The only point I would make here is that the decisional referents which are brought to bear on agency decisions are frequently a function of the agency's procedural organization.

What is required is the conceptualization of principles and analyses used in

${ }^{97}$ See Sperry \& Hutchinson Co., 69 F.T.C. III2, Irr5-16 (I966) (Elman, dissenting).

${ }^{08}$ M. Berger, Equality by Statute I93 (Rev, ed. Ig68).

${ }^{90}$ See the discussion of the stringent approach to cost-justification questions which the Commission has employed in M. Adelman, A \& P: A Study in Price-Cost Behavior and Public Policy i64-7I (x959). Adelman here criticizes Commission disallowance of cost studies which appeared to have evident validity but which contain cost elements some of which may be unprovable. Accord, U.S. ATTORNEY General's National Comantiee to Study the ANTtrRust Laws, Report i70-76 (I955). Although cost-accounting data appear to be important tools of management, businessmen do not appear to base their actions on cost-accounting data which would prove accepeable to the Commission. See M. ADELMAN, supta at 165 2.24. See also C. Edwards, The Price Discrimination Law 600 (1959). Cf. A. Sawyer, Businesss Aspects of Pricing Under the Robinson-Patalan Act I23 (1963).

${ }^{100}$ Aucrbach, The Federal Trade Commission: Internal Organization and Procedure, 48 MrnN. L. REv. 383, 498-500 ( 1964 ). Even under existing organization, accounting advice could be proffered by an accountant to the hearing officer or to the Commission so long as the individual proferring that advice had not participated in the investigation or prosecution of the case (and, by extension, so long as his supervisor had not so participated). 
the specialized disciplines and, where appropriate, in other areas of collective social or business experience, as decisional referents in a way not very different from the way in which rules are used as decisional referents. Today many decisional referents employed by officials purport to be based upon specialized disciplines but could not withstand critical scrutiny from professionals of those disciplines. Thus, for example, many decisions of the courts and of the Federal Trade Commission which attempt to determine the competitive effects of discriminatory pricing grossly misapply microeconomic theory. ${ }^{101}$ And the decisions of public utility regulatory bodies often seem to operate in ignorance of the concepts of demand elasticity and of marginal-costpricing, concepts that seemingly ought to constitute important decisional referents for them. ${ }^{102}$ Yet these and other referents escape correction because they come to light only in their ad hoc application. If and when the suggested reconceptualization begins to occur, we will perhaps more fully appreciate that an economic or social misconception in one case sometimes may be symptomatic of a chronic use of decisional referents which are based upon ignorance or misinformation.

The discussion of the use of specialized disciplines as decision referents thus points up the fact that exposure-or openness-is not the only factor required. To the extent that specialized disciplines are, or should be, the decisional referents, the decision-making process must in some way bring in those who possess the requisite skills in those disciplines. ${ }^{103}$ Otherwise outside criticisms that the agency officials have misapplied or misunderstood the disciplines will necessarily go unheeded. ${ }^{104}$ Unless persons possessing the requisite skills are themselves utilized in the decisional process, the decision cannot reflect those skills. The moral, then, in the situations we have referred to is for the Federal Trade Commission to utilize its accounting and economic staff in decisions dealing with cost-justification and the competitive effects of pricing and for public utility commissions to utilize the services of skilled economic technicians in their rate-regulation decisional processes.

The point-not just of exposure-but of exposure to critical persons within the agency structure and, in some situations, the incorporation of those persons in the decisional process is especially important in connection with agency decisions whose referents cannot be fully exposed to public view. Thus, for example, budget allocation decisions which substantially restrict resources available for specific kinds of enforcement activities often cannot be fully disclosed to the public without impairing the deterrent effects of agency enforcement. ${ }^{105}$ Yet complaint-issuance and other decisions within the agency structure ought to utilize the budget decisions as referents. They can do this, however, only if persons fully acquainted with the

\footnotetext{
${ }^{10 x}$ See note 88 supra.

108 See J. Bonbright, Princtiples of Public UtiLtTy Rates 315-16 (196r).

${ }^{103}$ H. Simon, AdMinistrative Behayior 82 (2d ed. 1957).

${ }^{104}$ Because they will not be understood. Competence in a discipline is a prerequisite for understanding criticisms made in the language of that discipline.

${ }^{105}$ See, e.g., Gifford, Communication of Legal Standards, Policy Development, and Effective Conduct Regulation, 56 CORNELI L. REV. 409, 436 (1971).
} 
implications of the budgetary decisions are involved, either as participants in complaint-issuance and related kinds of decision-making, or as participants in the review of those decisions.

\section{V}

\section{The Impact of Recent Developments in Judicial and Administrative "Standing" Upon the Choice of Decisional Referents}

Recent developments in the law of standing have as their ultimate effect the designation of new or preferred referents for administrative decision-making. Let me trace the major outlines of that development in an effort to show the interaction of standing and the designation of new decision-making referents. In order to do this I must first describe certain aspects of the Sanders ${ }^{106}$ and Associated Industries ${ }^{107}$ cases, cases which are familiar to all students of administrative law. This description will enable me to make some points about the post-Scenic Hudson $I^{108}$ developments in standing and the relation of those developments to the designation of new decisional referents for administrative bodies.

In Sanders, the Supreme Court displayed a willingness to differentiate between the subject-matter of a claim and the motivation for bringing suit. It is true that it had previously displayed such a willingness at times, ${ }^{109}$ but in Sanders it began a radical expansion of standing to obtain judicial review of administrative action by reading this differentiation into the judicial review provisions of the Communications Act. The Communications Act provided for judicial review of decisions of the Federal Communications Commission at the instance of any person aggrieved or adversely affected by that decision. ${ }^{110}$ In Sanders, the Court construed the terms "aggrieved" and "adversely affected" as they appeared in the Communications Act as conferring standing upon an existing radio station to challenge in court a Commission decision granting a new license to a rival station. ${ }^{111}$ The Court, in reaching this result, differentiated between the substance of the claim being asserted and the grounds upon which the objecting radio station was permitted to assert that claim. The claim was that the issuance of the license was inconsistent with the public's right to quality radio service. A public right was being asserted and the issues and

\footnotetext{
${ }^{100}$ FCC v. Sanders Bros. Radio Station, 309 U.S. 470 (I940).

${ }^{107}$ Associated Indus. of N.Y. State, Inc. v. Ickes, I34 F.2d 694 (2d Cir. 1943).

${ }^{108}$ Scenic Hudson Preservation Conference v. FPC, 354 F.2d 608 (2d Cir. I965), cert. denied, 384 U.S. $94 \mathrm{I}$ (1966).

${ }_{100}$ Thus, for example, in Pierce v. Society of Sisters, 268 U.S. 5 I0 (x925), the Court permitted affected and motivated persons to assert the rights of others. In Pierce a religious organization which operated a private school was permitted to assert the rights of parents to send their children to a school of their choice against a state law which interfered with that right. See also the later case of Barrows v. Jackson, 346 U.S. 249 (r953), in which a white defendant was permitted to assert the rights of unidentified blacks in a defense to an action for damages for breach of a restrictive covenant.

${ }^{110}$ Under $\$ 402(b)$ of the Communications Act, an appeal of a Commission decision could be taken by an applicant for a license or permit or "by any other person aggrieved or whose interests are adversely affected by any decision of the Commission granting or refusing any such application."

${ }^{111} 309$ U.S. at $476-77$.
} 
arguments were required to be directed to the vindication of the public interest. ${ }^{112}$ Implicit in the Court's reasoning is the assumption that for the public right to quality radio service to be effectively maintained, that right-and the need for Commission consideration of factors underlying the preservation of that right-had to be pressed upon the courts. Indeed, since the judicial system works within an adversary framework, it is necessary that an advocate press the public right to quality radio service before the courts if the judiciary is to be able to accord it meaningful protection.

Since the existing radio station would be economically injured by the grant of a license to a second, competing station (because the available advertising revenues would now be shared between the two stations), the existing station would have a strong motive to try to prevent the licensing of a rival. ${ }^{113}$ That motive, the competence of the existing station to bring forward the appropriate legal arguments bearing on the public interest, and the absence ${ }^{114}$ of other persons or firms able, willing, and as strongly motivated, to present the public case against Commission action, gave the Court the basis for recognizing the standing of the existing station. Later, the provision allowing standing to persons "aggrieved" or "adversely affected" within the meaning of the Communications Act was construed to allow public-interest standing to an existing station to raise public interest arguments challenging the issuance of a license to another station, when the operation of the second station would allegedly cause electrical interference with the existing station's operations. ${ }^{115}$ The potential electrical interference was seen as ensuring that the existing station would be sufficiently motivated to press the requisite public interest arguments against the Commission's licensing decision before the court. Apart from the different source of motivation, the other factors justifying standing were the same as in Sanders.

Prior to Sanders, the meaning of the term "aggrieved" was unclear. ${ }^{116}$ After that decision the term "aggrieved" in the Communications Act was understood to confer standing upon existing radio stations whose economic interests would suffer when licenses were issued to rivals, although the standing conferred by that Act was understood as allowing existing stations to present only public interest arguments on the public's behalf. But the implications of Sanders ran deeper. The term "aggrieved" appeared also in other statutes. Especially in statutes using that term to confer standing which were enacted subsequent to the Sanders decision, it could now be

\footnotetext{
112 The Court concluded that no person could have a "property right" in the airwaves as a result of a license grant and that the Act was not designed "to protect a licensee against competition." 309 U.S. at 475. Nonetheless, the Court concluded that Congress could properly confer standing upon one likely to be financially injured by the issuance of a license "to bring to the attention of the appellate courts errors of law in the action of the Commission in granting the license" Id. at 477. Consistent with these two conclusions, the Court's opinion suggests that the rights vindicated by the appeal would be not those of the appellant but those of the public. See id. at $475-76$.

118 309 U.S. at 477.

114 Id.

${ }^{115}$ NBC v. FCC, $1_{32}$ F.2d 545 (D.C. Cir. 1942), affd, 319 U.S. 239 (r943).

${ }^{110}$ Cf. L. Jaffe, Judicial Controd of Administrative Action 516 (1965).
} 
inferred that Congress used that word advisedly. ${ }^{117}$ The word could be seen as a legislative attempt to incorporate the expanded conception of standing which Sanders read into the term "aggrieved."

In the mid-I940's Judge Frank's imaginative opinion in Associated Industries $\nu$. $I c k e s^{118}$ gave further conceptual form to the new public-interest standing doctrine begun in Sanders. There the court confronted a challenge to a decision by the Department of the Interior's Bituminous Coal Division raising coal prices. The challenge was made by an association whose members collectively consumed large amounts of bituminous coal. In granting standing to the association, the court observed that the Bituminous Coal Act conferred standing upon persons "aggrieved" by decisions of the Bituminous Coal Board ${ }^{119}$ and that the term "aggrieved," as used in the Communications Act, had been interpreted in Sanders and $K O A^{120}$ to confer standing upon radio stations suffering economic injury or electrical interference as a result of administrative action to address legal arguments on behalf of the public to the court against that administrative action. The court then concluded that the standing provision in the Bituminous Coal Act, by employing the term "aggrieved," incorporated the Sanders doctrine of expanded public-interest standing. ${ }^{121}$ It concluded that the standing conferred upon radio stations to challenge FCC decisions exposing them to new competition or to electrical interference were explainable on the ground that their subjection to that competition or interference gave them a strong motive to press public interest arguments. Since the association challenging the Bituminous Coal Division decision represented firms economically injured by the Division's action, the court found that the association and its members had the same kind of motivation to make public-interest arguments as had the radio station in Sanders. On this basis the court granted the association standing to make legal interest arguments against the division action.

In support of his decision granting standing, Judge Frank developed his nowfamous characterization of the position of the association, or, indeed, of any Sanderstype plaintiff, as private attorneys general. ${ }^{122}$ In this way Judge Frank laid to rest serious constitutional challenges to the then-emergent public-interest type of standing. Since Congress could authorize the Attorney General to seek judicial relief against commission action extending beyond its statutory mandate, it could as easily confer standing on others to challenge such action by, in effect, creating private or ad hoc attorneys general to vindicate the public interest in lawful commission action in particular cases. In order to ensure that these private attorneys general effectively represented the public interest, Sanders required that the private person have a strong

\footnotetext{
${ }^{117}$ See, e.g., Associated Indus. of N.Y. State, Inc. v. Ickes, I34 F.2d 694, 705 (2d Cir. I943).

${ }^{118} 134$ F.2d 694 (2d Cir. 1943).

${ }^{210}$ Bituminous Coal Act of r937, ch. 127, $\$ 6(\mathrm{~b}), 50$ Stat. 72.

${ }^{120}$ NBC v. FCC, 132 F.2d 545 (D.C. Cir. 1942), aff'd, 319 U.S. 239 (1943).

$121 \times 34$ F.2d at 705 .

222 Id. at 703.
} 
objective motivation. ${ }^{123}$ That motivation was found here and in Sanders in economic injury which the challenged agency action caused the objector. ${ }^{124}$

But while standing in Associated Industries could be established relatively easily from Sanders once the court focused upon the factors of economic injury, the public interest need for unlawful commission action to be challenged, and the scarcity of effective private challengers other than consumers of coal or their representatives, Associated Industries itself is an important milestone in the evolution of the law of standing. First, the economic injury recognized as a basis for standing was injury to a consumer interest. ${ }^{125}$ While the felt harm may be just as great whether the injury occurs in the form of increased costs of fuel or a decrease in advertising revenues, the recognition of the consumer class as possessing an interest capable of conferring standing opened the gates to a vast increase in the number of persons potentially capable of challenging agency action. ${ }^{126}$ Second, while the Court struggled in Sanders to differentiate the interest conferring standing from the arguments which could appropriately be made by the station accorded standing, ${ }^{127}$ that distinction became less clear in Associated Industries. In Sanders, there was an overlap: the public interest did extend to the economic well-being of the radio station, but only insofar as a degree of well-being was essential to ensure adequate service to the public. ${ }^{128}$ In Associated Industries, the public interest in bituminous coal prices which are not unduly high appears almost co-extensive with the interest of consumers in preventing such price increases. ${ }^{129}$ Later cases recognized consumer interests as a basis for challenging agency action increasing prices under a number of price or rate-regulating statutes. ${ }^{130}$ In most of these cases the objectors were industrial consumers. The liberalization of the law of standing which began in Sanders and

\footnotetext{
${ }^{128} 309$ U.S. at 477 .

124 I34 F.2d at 705.

125 Id.

${ }^{120}$ Cf. 134 F.2d at 707 .

${ }^{127} 309$ U.S. at $475-77$.

${ }^{228}$ Id. at 476.

${ }^{129}$ The differentiation of the public interest claim from the grounds which give rise to standing to assert that claim made sense in Sanders where the public interest was in quality broadcasting service -and implicitly in conformity by the Federal Communications Commission to procedures designed to vindicate that public interest-and the grounds which gave rise to standing consisted of economic injury to an existing licensee. Even though some economic injury to an existing licensce would impair scrvice, not every such economic injury had that potentiality: economic injury which diminishes the licensee's profits but which leaves him with a sevenue margin sufficient to maintain service lacks that potentiality. And service can be impaired otherwise than by impairing the revenue margins of existing licensees. In Associated Industries, however, the ground giving rise to standing is that the approved price increase economically injures the consumers granted standing. And a public right to be asserted is that the rates must not be unreasonably high. A situation in which the ground giving rise to standing and the publicinterest claim would not overlap would be that in which a consumer was injured as the result of a rate increase which was a reasonable one. In that case the consumer who would be granted standing would lose his case on the merits. This is not, of course, to say that the grant of standing in such a case would be useless, for it is only after the standee litigates his public-interest claim that the claim is officially determined to be lacking in merit.

${ }^{280}$ E.g., City of Pittsburgh v. FPC, 237 F.2d 74 I (D.C. Cir. I956).
} 
was extended in Associated Industries had consequences that by and large were confined to the industrial and commercial sectors of American life.

But in 1965 the United States Court of Appeals for the Second Circuit rendered its decision in Scenic Hudson Preservation Committee v. FPC. ${ }^{131}$ That case involved the issuance of a license by the Federal Power Commission to Consolidated Edison Company for the construction of a pumped storage hydroelectric project on the Hudson River. After the Commission's decision, an association of neighboring landowners which had been a party to the licensing proceedings before the Commission asked the court of appeals to invalidate the Commission's license grant. The court accepted the case and reversed the Commission's decision largely because the Commission had made its licensing decision primarily on engineering grounds and had neglected to consider esthetic and environmental factors in its decision. ${ }^{132}$ Yet in order to do this, the court had to come to grips with the standing issue raised by the association's petition to the court. The Federal Power Act conferred standing upon "aggrieved" parties," ${ }^{133}$ and the court found standing in the association under the Sanders and Associated Industries rationales. ${ }^{134}$ Here, however, the court indicated that a personal economic interest was not a prerequisite to suit. ${ }^{135}$ It thus differentiated Scenic Hudson from the consumer cases symbolized by Associated Industries. The court then went on to say that "those who by their activities and conduct have exhibited a special interest" in the "aesthetic, conservational, and recreational aspects of power development" would be held to be within the class of "aggrieved" parties under the Federal Power Act. ${ }^{136}$ In this way the court solved the motivational problem: it found proof of strong motivation from the plaintiffs' actions, especially their actions in contesting the license in question. It is difficult to fault the court for this: the logic of Sanders and Associated Industries requires strong motivation in the plaintiff. And motivation can be strong even if it is not economically grounded. And since the court felt that the public interest included the "aesthetic, conservational and recreational" factors pressed by the associa-

\footnotetext{
${ }^{131} 354$ F.2d 608 (2d Cir. I965), cert. denied, 384 U.S. 941 (xg66).

${ }^{102} 354$ F.2d at $620,624-25$.

${ }^{133}$ Federal Power Act, I6 U.S.C. $\$ 825 l(b)$ (1970).

284 354 F.2d at 615 .

${ }^{186}$ It so indicated in its rejection of the Federal Power Commission's contention that the association lacked standing because it made "no claim of any personal economic injury resulting from the Commission's action." In that rejection the court asserted that the Federal Power Act seeks to protect noneconomic as well as economic interests and observed that the Supreme Court "has not made economic injury a prerequisite where the plaintiffs have shown a direct personal interest." 354 F.2d at 6r5. The court reenforced its decision on standing, however, by finding that such an economic interest was possessed by one of the member organizations of the plaintiff association in its ownership of seventeen miles of trailways which would be flooded by the project's reservoir. It also found that towns which were co-petitioners with the association had standing because the transmission lines connected with the project "would cause a decrease in the proprietary value of publicly held land, reduce tax revenues collected from privately held land, and significantly interfere with long-range community planning." Id. at $6 \mathrm{I} 6$.

${ }^{130} 354$ F.2d at $6 \mathrm{I} 6$.
} 
$\operatorname{tion}^{137}$ and since others were not likely to press those factors, the rationales of Sanders and Associated Industries indicated that the association should be given standing to assert these factors on behalf of the public.

In Scenic Hudson, however, the latent implications of the earlier cases are exposed. Sanders and Associated Industries granted standing "to vindicate the interest of the public." But there is no one public interest. Both cases implicitly acknowledge this when they note that standing is granted in order that needed "legal" arguments $^{138}$ may be brought to the court's attention. If the public interest is conceived as one concerned with correcting any illegal action by an agency, then anyone who can point out an error of law which would otherwise go unnoticed should be given standing. The existing broadcast licensee and the industrial association will bring needed arguments to the court's attention, but so will the new licensee, the Federal Communications Commission, and the Bituminous Coal Division. The existing licensee and the industrial association have a motive to point out some errors of Iaw by the agency; they have no motive at all to point out errors of law in their favor. The public-interest characterization thus tends to obscure the fact that the public-interest plaintiff brings to the court's attention only some of the arguments which the court requires to understand the case and to decide it correctly. In Scenic Hudson the administrative illegality which the public-interest plaintiff is pressing the court to consider consists in the Federal Power Commission's neglect, in its decisional processes, of "aesthetic, conservational and recreational" factors, factors which constitute only a portion of the factors which the Commission must consider. Since the public-interest plaintiff apparently was prepared to challenge the legality of the administrative proceeding only on the ground of the Commission's failure to grant adequate consideration to "aesthetic, conservational and recreational" factors, the grant of public-interest standing in the Scenic Hudson case is transparently a grant of standing to vindicate only a part of the public interest. The association supplied the mechanism for pressing the need to consider the "aesthetic, conservational and recreational" factors, but it would play no role at all in ensuring that other factors were properly taken into account. Public-interest standing now clearly appears as standing to press particular factors or values or points of view.

But this statement of the case is incomplete because we are dealing with a decisional process which takes place on two levels: at the agency level and in the courts. At the court level, the grant of standing to the association served the Sanders purpose of enabling the court to be informed why the Commission decision was

\footnotetext{
187 Id.

${ }^{188}$ The Court's reference in Sanders, as well as in much of its progeny, to undefined-and hence more-or-less abstract-"errors of law" in the action of the agency which the public-interest standec will bring to the attention of the appellate court tends to gloss over the fact, which clearly appears in Scenic Hudson, that the errors of law which a standee raises may be limited to those connected with a particular concern of the standee such as the agency's insufficient attention to aesthetic factors in Scenic Hudson or to nondiscriminatory programming in Office of Communication of United Church of Christ v. FCC, 359 F.2d 994 (D.C. Cir. 1966).
} 
wrong. But the case is different from Sanders because it was assumed that the objecting radio station would muster all of the "public interest" arguments available to defeat the FCC's licensing. The grounds for standing were conceived to be different from the substantive grounds urged before the court for invalidating the agency decision. In Scenic Hudson, by contrast, the grounds for recognizing standing are activities and conduct in the very areas which are pressed before the court. The court's grant of standing to the association is seen not so much as a general charge to bring forward any and all "public interest" arguments against the agency's action, but as a charge to bring forward arguments in the area in which the association has demonstrated its interest and competence-in presenting the aesthetic, conservational, and recreational arguments against licensing. ${ }^{138}$ At the court level, therefore, our earlier conclusion thus remains true: public interest standing as it appears in Scenic Hudson is standing to press particular factors or values or points of view. But in deciding Scenic Hudson, the court perceived the association not only as pressing aesthetic, conservational, and recreational factors before it-in the sense of urging the court to command agency attention to those factors-but as pressing them at the agency level as well. Indeed, the court saw standing in court as a necessary adjunct to standing at the administrative level. Because these aesthetic, conservational, and recreational factors should be considered by the :Commission, it was necessary to grant judicial standing to the association in order to enable the association to alert the court when the Commission has inadequately attended to these factors. ${ }^{\mathbf{1 4 0}}$ Public interest standing in Scenic Hudson, therefore, necessarily involves the pressing of particular factors or values or points of view at the administrative level as well as on the level of court review.

In its total effect, then, Scenic Hudson uses the pre-existing standing law as a base for deciding that aesthetic, conservational, and recreational factors should be taken into account by the Commission-that (in our earlier terminology) ${ }^{141}$ they should be made "referents" for Commission decisions. In remanding the proceeding to the Commission, the court utilized the association as a mechanism for pressing these referents upon the Commission and for bringing out before the Commission information and arguments geared to the utilization of these referents in the licensing proceeding. In summary, then, (i) Scenic Hudson saw public interest standing as a device to bring some factors or values or points of view into the decisional process; (ii) these factors or values or viewpoints are made "referents" in the sense that they must be taken into account, although here, at least, they constitute some, but not all, of the "referents" which the decision-making body must take into account; (iii) judicial standing is employed as a device to enable the court to compel agency attention to those referents; but (iv) the mechanism which carries through-which presses these judicially articulated referents upon the agency-is the association

\footnotetext{
${ }^{100} 354$ F.2d at $6 \mathrm{r} 6$.

${ }^{100}$ Id. Compare Sierra Club v. Morton, 405 U.S. 727 (1972).

141 See text accompanying note 26 supra.
} 
itself. $^{142}$ Judicial standing, therefore, is the tip of the iceberg through which the court reshapes the decisional process at the agency level. But, it will be asked, does this summary accurately describe a process through which the decisional process can be reshaped in other cases as well? The review provisions involved in such cases may-as did the review provisions of section I3 $_{3}$ of the Federal Power Act, ${ }^{143}$ which was involved in Scenic Hudson-require that the "aggrieved" person seeking review must be a party to the agency proceeding. And in Scenic Hudson, the court expressly recognized the agency's power to limit intervention. ${ }^{144}$ Here the answer must be that the court which wishes to reshape the decisional structure in the manner outlined will have to require $\mathrm{H45}^{\mathbf{1 4 5}}$ that the agency admit as an intervenor a proponent of the factors which the court thinks should be considered in such a restructured decisional process.

From this point, the Church of Christ cases ${ }^{140}$ follow naturally. In these cases the primary facet of decision was the standing of a church and others to intervene in agency proceedings. The court applied the Sanders arguments to grant administrative standing to a church which sought to represent viewers in television-licenserenewal proceedings before the Federal Communications Commission. ${ }^{147}$ The court observed-as in Sanders-that unless the churah or other listener representatives were given standing, arguments and information which the Commission needed in order to make a well-informed decision would be lacking. ${ }^{148}$ But although the court spoke of the church as a "listeners" representative, it is also true that the church was primarily the representative of the black population which objected to the television station's racially discriminatory broadcasts. ${ }^{149}$ The court thus saw the church as pressing, not "public interest" arguments in general nor even "listeners" arguments in general, but a concern primarily with racially nondiscriminatory pro-

${ }^{1<2}$ This is what the court contemplated in Scenic Hudson and what did in fact happen. Cf., e.g., 354 F.2d 6I7 where the court refers approvingly to representation of common interests at the administrative level by an organization such as Scenic Hudson which, by reducing the need for intervention by others with similar concerns, will "expedite the administrative process." Compare Norwalk CORE v. Norwalk Redevelopment Agency, 395 F.2d 920, 937-38 (2d Cir. 1968). In Norwalk the court, in treating judicial standing, indicated that the standing of an association of minority-group persons (adversely affected by a redevelopment agency's failure to relocate them on terms as satisfactory as those on which displaced white tenants were relocated) would depend upon whether individual members of the affected class could adequately represent the claims of the whole class before the court.

${ }_{143} 16$ US.C. $\$ 825 l$ (b) (1970).

$2 \$ 4354$ F.2d at $6 \times 7$.

${ }^{145}$ See, e.g., Office of Communication of United Church of Chirst v. FCC, 359 F.2d 995 (D.C. Cir. I966).

${ }^{140}$ Office of Communication of United Church of Christ v. FCC, 425 F.2d 543 (D.C. Cir. I969); Office of Communication of United Church of Christ v. FCC, 359 F.2d 994 (D.C. Cir. I966).

${ }^{147} 359$ F.2d at 1004-05.

$1+8 I d$.

${ }^{240}$ The court was conscious that the kind of public-interest administrative standing with which it was concerned involved representation of different groups in the listening community, and that, in ruling on petitions for public-interest intervention, the Commission would have to judge the usefulness for arriving at a correct licensing decision of adjudicating the claims asserted by the potential intervenors. 359 F.2d at 1005, roo6. 
gramming. ${ }^{150}$ Racially nondiscriminatory programming, a goal which the court saw as important, was also the special goal of the church and the black population which it represented. In order to make racially nondiscriminatory programming an effective referent for decision-making in the license-renewal proceedings, the court perceived a need for a greater input in the decision-making process of information and arguments addressed to the goal of racially nondiscriminatory programming. This need, the court saw, could be fulfilled in part by granting administrative standing to the church. By combining its own command to the agency to use the goal of racially nondiscriminatory programming as a referent with a grant of administrative standing to the church or to another listener representative associated with it ${ }^{151}$ the court ensured that the Commission would be continually reminded of that referent and that it would be pressed with information and arguments directed to the application of that referent. ${ }^{152}$ Again, then, the court utilized the spokesmen for a group of citizens having a particular interest or concern as a device for impressing a decision-making referent on an agency. This procedure was especially useful here because the Commission had continually acknowledged verbally its adherence to the same referent and, indeed, had used that acknowledgment as a reason for urging that the church's intervention to press that referent upon it was unnecessary. ${ }^{153}$ The decision thus emphasizes the court's felt differentiation between a verbal acknowledgement of a referent and decisions which in fact are made in the light of that referent.

In Scenic Hudson the court's utilization of the association as a device for pressing a referent upon a licensing agency was perhaps seen-even by the court-as entrusting the association with the primary responsibility for bringing forward before the agency information and arguments relating to the application of the aesthetic, conservational, and recreational referents which the court had approved. But in the second Church of Christ case where the Commission appeared to have seen the church-intervenor as primarily responsible for developing the case for applying the court-approved referent of racially nondiscriminatory programming, the court insisted that the implementation of that referent was primarily the responsibility of the Commission. ${ }^{154}$ The church-intervenor was cast by the court in the role of a complaining witness and the Commission as a prosecutor whose duty it is to ascertain whether probable cause exists for the complaint-here against the station-and, if so, vigorously to develop a case based upon such cause. ${ }^{155}$ In context, it seems that the court is demanding that the Commission not only (i) accept the referent of racially nondiscriminatory programming verbally (which it had previously done) and

\footnotetext{
${ }^{350}$ Other claims of the church and associated parties were some elements of religious discrimination, oppressive overcommercialization, and fairness doctrine violations. 359 F.2d at 1006.

252359 F.2d at 1006, I009.

${ }^{102} \mathrm{Id}$. at 1006, 1007, 1009.

${ }^{258} I d$. at $1004,1007-08$.

204425 F.2d at 546 .

${ }^{208}$ Id.
} 
(ii) be receptive to a case developed by the church-intervenor based upon that referent (in the manner of the Scenic Hudson procedure), ${ }^{156}$ but (iii) also take steps on its own to implement that referent, using the church-intervenor not as an advocate before it but as an aid for its own investigation and case-development. ${ }^{157}$ The referent thus becomes not merely one to which the agency must be receptive and which the agency will apply if others supply information and arguments requisite for its effective utilization, but one which the agency itself has the affirmative duty to employ. The "public interest" standee remains as the agency's "conscience," if you will, in applying the referent. It keeps the agency forcefully reminded of the referent and calls incidents and approaches to the agency's attention for exploration and investigation. The affirmative duty imposed on the agency is perhaps intended to magnify the agency's responsiveness to the standee's suggestions, a state of affairs which, if brought about, will heighten the importance of the referent in the agency decision-making process.

The law of public interest standing has thus developed from a tool for informing the judiciary of any or all available public-interest arguments which the standee wishes to make $\mathrm{e}^{168}$ into a device for restructuring agency decision-making by impressing new referents upon the agency and ensuring that those new referents are heeded. Church of Christ $I I^{150}$ gives referents to the decision-making agency in a dynamic form. They are imposed upon the agency together with a standee who presses the agency to relate to the referents. The standee's function is the agency's conscience and helper in applying the referent. And his role is both eased and strengthened by the magnified voice which he is given when the court makes the implementation of the referent in question an affirmative duty of the agency.

One way of viewing these cases would be to say that the courts are merely applying to agencies their long-standing rule of ensuring that judicial decisions are based upon adequate information. In this view the courts would be seen as enlarging judicial standing as a means of enlarging administrative standing. And they would be seen as enlarging administrative standing in order to ensure that information needed by agency decision-makers is brought before them. But one difficulty with such a narrow view is that agencies almost always have access to the information which they need to make informed decisions. The courts are saying something more. They are saying that the decisional perspective from which the agency in question approached its problem was too narrow, that its decisional frame of reference needs to be broadened, and that it needs exposure not only to additional

${ }^{10 B}$ But cf. notes 157 \& 162 infra.

${ }_{107}$ Cf. Scenic Hudson Preservation Conference v. FPC, 354 F.2d 608, 620 (2d Cir. 1965), cert. denied, $3^{8} 4$ U.S. 94I (Ig66): ("the Commission has claimed to be the representative of the public interest. This role does not permit it to act as an umpire blandly calling balls and strikes for adversaries appearing before it; the right of the public must receive active and affrmative protection at the hands of the Commission."). Accord, Calvert Cliffs' Coordinating Comm., Inc. v. AEC, 449 F.2d 1x09, x119 (D.C. Cir. 1971).

${ }^{158}$ FCC v. Sanders Bros. Radio Station, 309 U.S. 470, 477 (1940).

${ }^{280} 425$ F.2d 543 (D.C. Cir. 1969). 
information but that it needs to utilize new decisional referents. The choice of the kinds of information which the agency will employ and the factors which it will consider, these courts are saying, is not entirely the agency's to make. But this, of course, is nothing new. Courts have long exerted a power of review over agency choices of decisional referents, either rejecting some as improper or requiring agency consideration or use of other referents. ${ }^{180}$ What is new in these cases is the combination of the judicial imposition of referents with the grant of administrative standing to proponents of the referent which is imposed. These courts are thus saying that the information to be acquired by the agency in question and the referents to be used by it need not only to be approved judicially but also to be vigorously pressed upon the agency by a proponent of the enlarged frame of reference.

The referent-proponent is thus cast in a two-fold role which corresponds to the changes in agency decision-making which these decisions are designed to achieve. First, the proponent is cast by the court in the role of pressing the agency to orient its processes in line with the new or previously unheeded-but generally phrased-referents which it is championing. The proponent must continually exert pressure upon the agency to consider these referents in its own decisional processes, and, if it fails, the proponent is given standing to seek judicial review on the ground that these referents have been neglected. The proponent's function here is partly one of reenforcing the court's orders about the frame of reference in which agency decisions are to be made. Thus Church of Christ II utilizes the analogy of a complaining witness and the prosecutor ${ }^{101}$ in order to compel the agency staff not only to take seriously the new decisional referent (the furtherance of racially nondiscriminatory programming as a conduct norm for radio and television licensees) but to develop the case which active employment of that referent requires. Judge Wright in National Welfare Rights Organization $v$. Finch ${ }^{162}$ seeks to accomplish the same result by forcing the Department of Health, Education, and Welfare to accept the NWRO as a party to compliance proceedings which the Department had instituted against two states. The court is saying that the best insurance that the administrators take into account the attitudes, views, and information which welfare recipients have to contribute consists in making their representatives parties to those administrative proceedings which decide policies affecting them. Again, the court is not merely helping HEW obtain the information it requires. HEW, if it has the interest and motivation, undoubtedly has the capacity to collect all of the information which it will get in the court-mandated procedure. But Judge Wright's point is just that it may lack that motivation. The rigidities in approaches to decisions imposed or fostered by its own bureaucratic organization may create inertia

\footnotetext{
${ }^{100}$ E.g., NLRB v. Hearst Publications, Inc., 322 U.S. III (1944) (inapplicability of respondentsuperior and workmen's compensation principles for decision-making under the National Labor Relations Act). Congress later took a different view as to the relevancy of these sources as referents for labor board decisions. See 29 U.S.C. $\$$ I52(3) (I97I).

161425 F.2d at 546 .

${ }^{102} 429$ F.2d 725 (D.C. Cir. I970).
} 
to changes in its selection of decisional referents unless new decisional foci are pressed vigorously upon it. ${ }^{103}$ And the granting of administrative standing to NWRO was apparently designed to do just that. Although here the agency organization was not made part of the mechanism by which the application of the decisional referents were applied as in Church of Christ II, the court recognized ${ }^{104}$ the need to alter the decisional process at the administrative level in such a way as to make it both open and receptive to new decisional referents supplied by welfare recipients' representatives.

The referent-proponent is given a second role under the recent cases. Because the judicially-approved referents are often phrased in general and, hence, openended language-such as the "aesthetic, conservational and reoreational" factors referred to by the court in Scenic Hudson ${ }^{165}$-the referent-proponent is charged not only with a reenforcing function at the agency level but with a development function as well. It is charged with the function of pressing the agency to come to grips with the concerns which the court has approved in generalized language in the specifics of a concrete case. This calls for imagination, initiative, and perseverance. It may be easier to concretize the concerns of the welfare recipients involved in the $N W R O$ case than to concretize the environmental concerns involved in cases like Scenic Hudson. In cases of the latter type the interplay between a broad concern with environmental quality and engineering considerations may require the publicinterest representative to possess technical skill if his representation is to be effective. $^{\text {168 }}$

The Supreme Court's twin decisions on standing under the Administrative Procedure Act-Association of Data Processing Service Organizations, Inc. v. Camp ${ }^{107}$ and Barlow v. Collins ${ }^{188}$ - expand the standing rights of persons injured or potentially injured by agency action. These cases create the mechanism through which questions as to the types and extent of protections created by statute can be judicially resolved. And in that resolution, agencies will be at least verbally required to develop the decisional referents necessary to accord those protections. Taken by themselves, the apparent weaknesses of these cases appear to lie in the absence of a mechanismdiscussed in those cases-through which the judicially determined referents will be reenforced and developed at the administrative level. But in combination with Judge Wright's decision in $N W R O$, they may exert a growing impact upon the choice of decisional referents by officials and agencies. In NWRO, Judge Wright

\footnotetext{
${ }^{108}$ Cf. Elman, Administrative Reform of the Federal Trade Commission, 59 Gro. L.J. 777, 789-92 (I97I) (pointing out that in the absence of consumer representation before it, the Commission, itself a consumer-protection agency, may neglect the consumer interests in its decisions).

206429 F.2d at $736-39$.

${ }^{105} 354$ F.2d at 616.

${ }^{100}$ Cramton, The Why, Where and How of Broadened Public Participation in the Administrative Process, 60 Geo. L.J. 525, 526-27 (1972).

${ }^{107} 397$ U.S. I50 (1970).

${ }^{108} 397$ U.S. I59 (1970).
} 
granted judicial standing-under the Data Processing and Barlow cases ${ }^{169}$-to the National Welfare Rights Organization to seek judicial review of compliance proceedings which HEW had brought against two state welfare departments. But he then reasoned that judicial standing, to be meaningful, presupposed standing at the administrative level. ${ }^{170}$ To the extent that Judge Wright's gloss on Data Processing and Barlow is followed, the dynamic characteristics of the Scenic Hudson and Church of Christ cases will be imparted to a wide range of administrative action.

Other recent cases-such as Citizens to Preserve Overton Park, Inc.v. Volpe ${ }^{171}$ and Medical Committee for Human Rights v. SEC ${ }^{172}$-have broadened vastly the scope of administrative horizons by insisting that the agencies whose action was under review utilize decisional referents which they had theretofore neglected or openly refused to employ or consider. Where the new referents can be forcefully urged and developed by competent "public-interest" representatives in agency-level proceedings, they carry the potential for dynamic referent development and reenforcement illustrated in the Scenic Hudson, Church of Christ, and NWRO litigation. But where the new referents are judicially ordered in a context which lacks a mechanism for their development and reenforcement at the agency level, as for example, where the absence of formal administrative proceedings precludes intervention of a public-interest representative, ${ }^{173}$ their promise appears not quite so bright as in the circumstances where that possibility is present. In this regard, legislatively-imposed procedures under the National Environmental Policy Act of $1969^{174}$ appear to be designed to impel the agencies governed by that Act to utilize environmental concerns as referents in ways that are meaningful. While the Act's mandates were forcefully imposed upon a reluctant Atomic Energy Commission at the insistence of a public-interest plaintiff in Calvert Cliffs, ${ }^{175}$ it is possible that even without the involvement of a public-interest representative the Act's mandated procedures (as construed in Calvert Cliffs) may themselves play the reenforcing role which is needed if the externally imposed referents are to be accepted and actively employed by the agencies.

\section{Summary and Conclusions}

I have tried to articulate a conception of agency decision-making which uses the concept of "decisional referents." As developed in the article, referents include, but are not limited to, "rules," criteria, factors, considerations, principles, policies, goals, and reasons. These all have their proper places in analyses of administrative decision-making, and the distinctions which can be made among them must not be lost. Agency-disclosed "reasons," for example, may sometimes be reviewed by

\footnotetext{
${ }^{200} 429$ F.2d at 733-35.

${ }^{170} 429$ F.2d at $736-37$.

171401 U.S. 402 (197I).

${ }^{172} 432$ F.2d 659 (D.C. Cir. 1970), vacated as moot, 92 S.Ct. 577 (1972).

17. $C f$. Citizens to Preserve Overton Park, Inc. v. Volpe, 401 U.S. 402, 420-2I (197I).

${ }^{174} 42$ U.S.C. $\$ 4321-47$ (1970).

${ }^{178}$ Calvert Cliff' Coordinating Comm., Inc. v. AEC, 449 F.2d Irog (D.C. Cir. I97I).
} 
the courts under a standard different from that under which agency "rules" are reviewed. But $I$ have attempted to find an inclusive concept in order to provide a tool by which the likenesses and the similarities in agency employment of these various factors can be assessed. The lawyer, conscious of the similarity in an agency's use of "goals" and "reasons" in its decisional processes, may be stimulated to look for each, rather than to rest after he is assured that the agency matter in which he is concerned is within the "discretionary" decision-making power of the agency. After he uncovers the relevant referent and notes the similarity in the ways in which "rule" and nonrule referents are employed, he will negotiate with agency officials in terms of the relevant decisional referent. He will present his case in terms of the governing referents and will take cognizance of those referents in shaping his arguments. This is how negotiation would be conducted when the case in question was governed by a "rule," and the negotiation process would seem to be essentially the same when the case is governed by a nonrule referent. The analogy to rulereferents may carry the lawyer further. Conceptualizing nonrule referents as analogous to rules, he would immediately sense the fact that somewhere in the administrative hierarchy is an official with power to change a referent or to waive its application. By facilitating the lawyer's perception of an appeal of the use of a nonrule referent, the lawyer may be stimulated to seek out and to find the particular official to whom he must address his arguments for the non-application of a referent to which the lawyer objects.

The usefulness of the "referent" concept must not be overstated. A perceptive lawyer would act in the ways just described, regardless of how he conceptualized the factors utilized by agency officials in deciding. A less perceptive lawyer, however, might not. The value of the concept, therefore, consists, first, in its capacity for demonstrating the manner in which "rules" blurr into nonrule decisional factors. The analogy to rules may help further in" assessing the likelihood (i) of obtaining relief from lower-echelon officials and (ii) of obtaining the time and attention of higher-echelon officials. Referents widely applied by numerous officials as a matter of course to large numbers of cases can be revoked, if at all, only by officials in the upper echelons of administration. For the same reason, higher echelon officials who might lack the time to review a routine case may make time to consider a major objection to a referent widely used by their subordinates. Again, officials will be reluctant to interfere unnecessarily with normal administration. The lawyer who can point out why a widely-used referent ought to be inapplicable to his case may be more successful than the lawyer who makes a broadside attack upon the basic propriety of the referent. The decisional-referent concept is offered for whatever stimulus it may afford to persons concerned with administrative decision-making to search out similarities among the ways in which various decisional factors are employed.

Second, the decisional referent concept is useful in illustrating the manner in which ad hoc or tentative decisional criteria blur into more fixed criteria. Davis, for 
example, has referred to the desirability of "rule" issuances by administrators who have arrived at "firm" answers to significant hypothetical cases. ${ }^{176}$ But long before an administrator has arrived at "firm" answers, he may have arrived at "tentative" answers. As time progresses these answers may become inoreasingly less "tentative" and more "firm." Yet the dividing line between tentative and firm answers may not be sharp. Davis's rule-issuance suggestion is a praiseworthy admonition directed to agencies; it is only indirectly addressed to the problem of a lawyer grappling with agency officials. 'The lawyer needs to learn the officials' decisional referents, even though they be "tentative" ones. The referent concept may aid him in perceiving the dimensions of his problem and in organizing his negotiation strategy.

Third, the referent concept is useful in demonstrating the manner in which the factors employed by individual officials blur into decisional factors employed by the subunits, units, bureaus, or agencies in which those officials work. Referents-whether of the rule or nonrule variety-differ in their authority bases. We have taken cognizance of this point above when we referred to the possibility of a lawyer appealing the application of a decisional referent to his case. This leads us to the fourth manner in which the referent concept may be useful. A focus upon the referents actually employed focuses attention upon informal rule and nonrule referents which arise from personal interaction among officials and which have often been the subject of inquiry by social scientists. ${ }^{177}$ These informal referents may "fill in" or "complete" open-ended formal rules, or, at times, may even effectively countermand them. The perceptive lawyer must be alert to the possibility that his client will be denied benefits to which he might otherwise be entitled because of the operation of such an informal decisional-referent structure.

Not only may the referent concept be helpful in engendering sensitivity to the existence of informal decisional referents, but, fifth, it may aid in understanding the processes through which such referents develop, change, and are reenforced. While, again, this is presently the domain of social scientists, I have, with some trepidation, tentatively expressed some of my own reflections on that subject in this article. Since the interaction of officials may affect the kind and quality of decisions, lawyers involved with administrative-law reform will, in the future, be increasingly concerned with the studies of complex organizations and with other findings of social scientists. In this article I have also made use of Davis's focus upon "openness," but as a factor affecting the degree of "substantive rationality" of the referents employed in deciding cases.

In connection with the foregoing approach, I have attempted to relate some contributions of legal philosophy. The probings of the legal realists are obviously relevant to a conceptualization of decision-making in terms of decisional referents. But the current linguistic school is also helpful in contributing to our understanding of referent-internalization. By focusing upon the contributions of Profesosrs H. L. A.

\footnotetext{
${ }^{170}$ K. Davis, Discretionary Justice 60 (1969).

${ }^{177}$ E.g., P. Blau, The Dymamics of Bureaucracy (2d ed. 1963 ).
} 
Hart and Dworkin in Part I, I have attempted to lay the foundations for an' analysis of decision-making in terms of decisional referents where those referents are often internalized by the official or sub-departmental group utilizing them. This initial focus upon internalization also prepared the way for a perception of the possibility that decisional referents might be generated by the personal interaction of officials involved in the decisional process. Finally, I have speculated as to the extent to which the more recent administrative-standing cases may work to expand the frame of reference in which agency decisions are made. Will agencies which are exposed to greater input from heretofore unrepresented interests become more responsive to those interests? And if they do become more responsive in formal proceedings in which these groups are represented, will the phenomenon of referent internalization carry over into informal actions by those agencies?

In summary, then, the article has utilized a conceptualization of decision-making in terms of decisional referents, and has attempted to explore the usefulness of this framework in increasing understanding or awareness of various types of administrative decision-making. 